\title{
Review
}

\section{Stanislav Grigoriev*}

\section{Andronovo Problem: Studies of Cultural Genesis in the Eurasian Bronze Age}

https://doi.org/10.1515/opar-2020-0123

received June 8, 2020; accepted November 28, 2020.

\begin{abstract}
Andronovo culture is the largest Eurasian formation in the Bronze Age, and it had a significant impact on neighboring regions. It is the important culture for understanding many historical processes, in particular, the origins and migration of Indo-Europeans. However, in most works there is a very simplified understanding of the scientific problems associated with this culture. The history of its study is full of opposing opinions, and all these opinions were based on reliable grounds. For a long time, the existence of the Andronovo problem was caused by the fact that researchers supposed they might explain general processes by local situations. In fact, the term "Andronovo culture" is incorrect. Another term "Andronovo cultural-historical commonality" also has no signs of scientific terminology. Under these terms a large number of cultures are combined, many of which were not related to each other. In the most simplified form, they can be combined into two blocks that existed during the Bronze Age: the steppe (Sintashta, Petrovka, Alakul, Sargari) and the forest-steppe (Fyodorovka, Cherkaskul, Mezhovka). Often these cultures are placed in vertical lines with genetic continuity. However, the problems of their chronology and interaction are very complicated. By Andronovo cultures we may understand only Fyodorovka and Alakul cultures (except for its early stage); however, it is better to avoid the use of this term.
\end{abstract}

Keywords: Andronovo culture, history of study, Eurasia

\section{Introduction}

The Andronovo culture of the Bronze Age is the largest archaeological formation in the world, except for the cultures of the Scytho-Sarmatian world of the Early Iron Age. In the $2^{\text {nd }}$ millennium BC, it was distributed in the center of Eurasia, within a huge territory from the Southern Urals in the west to the Yenisei River in Southern Siberia and western Xinjiang in the east. In the north, its border is the zone of southern taiga, and in the south, the Andronovo sites were studied in the south of Central Asia, in Tajikistan and Uzbekistan (Fig. 1). Therefore, this culture is always used when generalizing works on the Bronze Age of Eurasia; it is the main object in discussing the Indo-European problem, in discussing the history of Eurasian metallurgy, the formation of the Scytho-Sarmatian culture, the origin of ancient Chinese metallurgy and many others. However, in Western literature, ideas about this culture are often very simplified. Moreover, most Russian archaeologists who are not directly involved in Andronovo studies know only the most generalized outlines of this problem. In world archeology, there is no other problem with diametrically opposed points of view that are mutually exclusive. And this is not even the case when a new point of view replaces the old one. These mutually exclusive points of view coexisted in the Andronovo studies for many decades. This situation is partially preserved today. Therefore, it is no coincidence, in the 70s of the last century, a famous specialist in Sarmatian archeology K.F. Smirnov said: "When I go through a difficult time, I remember that I'm not doing Andronovo studies, and I'm feeling good!"

Moreover, the content of the concept "Andronovo culture" in the representations of various specialists involved in these studies is so different that this term is not used as a scientific term or is used by people who are poorly familiar

\footnotetext{
*Corresponding author: Stanislav Grigoriev, South Ural Department, Institute of History and Archeology, Ural Branch of the Russian
} Academy of Sciences, Chelyabinsk, 454080, Russia, E-mail: stgrig@mail.ru 


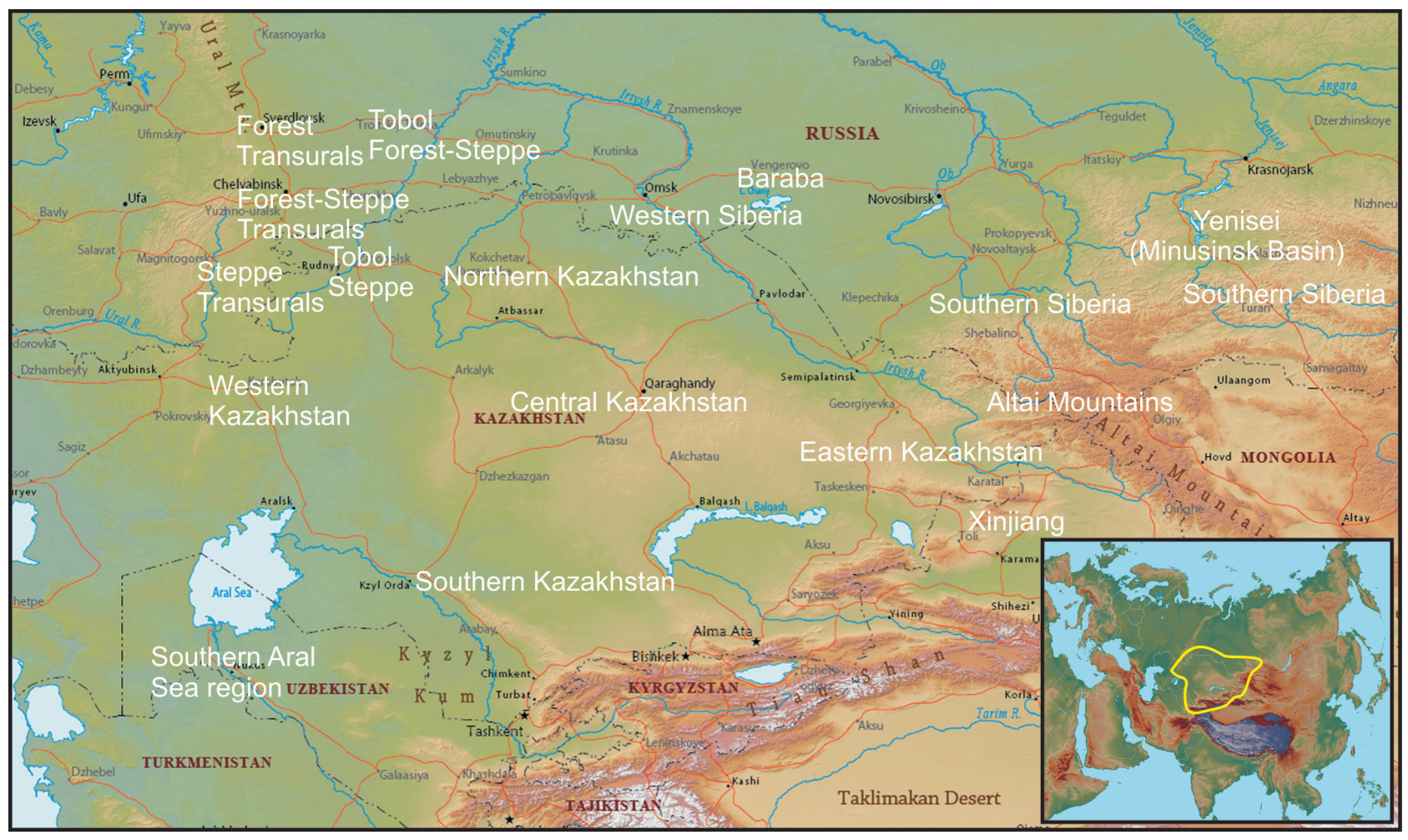

Figure 1: The distribution area of the Andronovo sites on the map of Eurasia and geographical areas mentioned in the text.

with the problem. There are many cultures within the Andronovo culture. Therefore, the concept under discussion is completely meaningless from a taxonomic point of view. As a result, it has not been used in real Andronovo studies for many decades, and the term "Andronovo cultural-historical commonality" ${ }^{1}$ is used. Notablly, the context of this term is so different that the term exists only by inertia. This term, without any alternative rationale, was introduced into the scientific circulation by A.A. Formozov (1951) to somehow combine these materials. For a long time, this term was not used. It was remembered only in the 70s. As we will see later, its meaning transformed repeatedly, almost disappeared, but the term has been preserved. Although for many years of its existence, no one even made an attempt to present it as a clear scientific concept (Bobrov, 2014, p. 275).

A scientific concept differs from a simple definition in that it does not just name an object but demonstrates principles of its functioning. This article shows that at this stage it is practically impossible to give the concept of the Andronovo cultural-historical commonality, since it depends on the acceptance of one or another theory of the Andronovo cultural genesis. Therefore, here we outline the framework of this article only at the level of the simple definition. In its pure form, "Andronovo" means materials of two cultures: Alakul and Fyodorovka. And the essence of the Andronovo problem is precisely in the interrelation of these two cultures. All other problems are secondary in relation to this. But since these cultures are spread over a huge territory, they influenced other cultures on the periphery, and Andronovo features appeared there. However, this does not give grounds to consider these cultures as Andronovo.

1 In English-language literature, this term is not used; usually all use the term "culture”. However, terminological issues are extremely important in this article. This term is inaccurate, since there are different cultures within the Andronovo culture. Russian authors use the term "Andronovskaya obshchnost", which has rather blurred boundaries, which makes it difficult to translate the term into English accurately. Therefore, some authors translate it in an equally vague form "family of cultures" (Grigoriev, 2002; Koryakova \& Epimakhov, 2007) or "cultural entity” (Kuz'mina, 2007). Sometimes the term "Andronovo community” is used, which is a more accurate translation of Russian terminology (Panyushkina, Mills, Usmanova, \& Cheng, 2008). However, in English, this term is more applicable to people or animals living in the same area, having common interests, and so on. But different cultures are united in the Andronovo community on a different basis: the similarity of some features of material culture. In reality, only on the base of similarity of some features in ceramics. Therefore, I preferred to use another term in this article: "Andronovo commonality". 
In western literature, for example, the Tazabagyab culture of the southern Aral Sea region is sometimes viewed as a variant of the Andronovo culture (Mallory \& Adams, 1997, p. 566). But experts on the Andronovo culture do not consider Tazabagyab as Andronovo.

It is important to note that the first investigator of this culture M.A. Itina emphasized the difference of these materials from the Andronovo and Srubnaya ones, although she suggested Srubnaya and Andronovo influences on the local Suyargan substratum during the formation of the Tazabagyab culture (Itina, 1977, pp. 111, 119, 176). On the northern periphery of the Andronovo area, there is a series of cultures that were also formed under the Andronovo influence: Cherkaskul, Suzgun, Elovka, Pakhomovo, and so on. No one considers them as Andronovo, although sometimes the term "Andronoid" is applied to them (Kosarev, 1981). It is not the final conclusion. In my opinion, the similarity of the Cherkaskul and Fyodorovka ceramics is such that the Cherkaskul can be considered as a territorial and chronological variant of Fyodorovka. So far this has not been reliably shown, and even if it is shown, I am not sure that this variant can be considered as Andronovo. Sometimes this problematic situation leads to paradoxes. Since the Alakul culture was formed on the Sintashta basis, G.G. Pyatykh proposed to consider the Sintashta culture as early Alakul culture (Pyatykh, 2003, p. 139). But Alakul is Andronovo culture. Therefore, E.E. Kuz'mina (2001, p. 87) suggested considering Sintashta as early Andronovo culture. But A.V. Matveev (1998, p. 358) rightly noted that the Potapovka complexes, on the basis of which the early Srubnaya culture of the Volga region was formed, are extremely close to the Sintashta ones. So, here, we may have a situation when similar sites in one area will be considered as early Srubnaya, and in another as early Andronovo. In the west of the Andronovo area, the main materials belong to the Alakul tradition. Fyodorovka materials are much less common. During a recent discussion with a colleague, I heard that, indeed, Alakul is based on Sintashta; therefore, this is also the Andronovo culture. But Fyodorovka is very specific and can be considered as Andronovo with great assumptions. But on the Yenisei, in a cemetery near the village of Andronovo, ceramics of the Fyodorovka type was discovered! Moreover, for our Siberian colleagues, just this culture is Andronovo for almost 100 years, and I doubt that we will be able to convince them to use the term "Fyodorovka" to their materials. And in the west, before the appearance of Fyodorovka culture or Fyodorovka features in Alakul, we have no right to name some complexes "Andronovo", based on the etymology of the term. Therefore, within the framework of this article, we will adhere to the traditional inclusion of two components in the Andronovo culture: Fyodorovka and Alakul. Any other cultures cannot be designated as Andronovo until it is shown by special studies.

Because of the paradox is that, as a rule, these mutually exclusive points of view were based on completely reliable grounds. Some views were rejected 50 years ago and forgotten, but now we see that they are relevant today, although even most Russian archaeologists are not aware of their existence. Some points of view sound odious today, but when we look at specific material, we understand that the stratigraphic situations and materials were understood and described quite correctly, but at that time there was no terminological apparatus for adequately reflecting the situation. And Andronovo materials are so rich and diverse that they are a kind of LEGO constructor, from which any shape can be assembled.

As a result, very often in new studies of some theoretical problems, fragments of theories are used that have always been oppositional in the Andronovo studies. For example, most supporters of the steppe homeland of Indo-Europeans believe that the Andronovo culture originated in the Urals, where the Alakul culture formed, and subsequently it transformed into Fyodorovka, which extended far to the east (Anthony \& Ringe, 2015; Parpola, 2012; Carpelan \& Parpola, 2017, pp. 138-141). Moreover, these theories are based on the works of the great Russian specialist in the Andronovo and Indo-Iranian studies, E.E. Kuz'mina. She really believed that the Andronovo southward migration reflected the spread of the Indo-Europeans (Kuz'mina, 2007), but she was perhaps the main opponent of the theory of the genetic continuity of various Andronovo cultures. Very often, Western colleagues cite works that reflect only one position, or some old works that do not correspond to the general level of Andronovo studies. Even Russian researchers, who hold the same position in the basic problem of Andronovo studies, can use it to justify diametrically opposed theories in Indo-European studies (cf. Grigoriev, 2002; Kuz'mina, 2007).

Thus, the Andronovo problem is not only saturated with paradoxes, but it also consists of them. The text will also lack the opinions on the dating of cultures, since the text would be saturated with many changing numbers, which are completely irrelevant at the present time. Moreover, often these numbers were based on false premises, which sometimes paradoxically led to the correct result even from the modern position, when two erroneous positions corrected each other. We will touch upon questions of chronology at the end, when all questions of periodization will be examined. 


\section{The Discovery of the Andronovo Culture. The Birth of a Paradox}

From time to time, monuments of the Andronovo culture were excavated in the Southern Transurals already in the second half of the $19^{\text {th }}$ century and in the first third of the $20^{\text {th }}$ century (Grigoriev, 2003, pp. 43-45). Their earliest publication was printed in 1863 (Zyryanov, 1863). Here the names of the publications ("Mounds in Shadrinsk District", "Chelyabinsk Mounds", etc.) reflect the lack of systematization, of a scientific approach, and at that time the Andronovo problem did not exist. It appeared in 1927, when two works were published. On the basis of excavations of a cemetery near the village of Andronovo on the Yenisei River in Southern Siberia S.A. Teploukhov (1927) suggested the new Andronovo culture ${ }^{2}$. M.P. Gryaznov (1927), after excavations of cemeteries in Western Kazakhstan, in the extreme west of the future Andronovo area, revealed stylistically similar complexes. Their difference was that the vessels in the east had a smooth profile (Fig. 2.1), and in the west in the upper part of the vessel there was a small ledge at the transition from the neck to the shoulder (Fig. 2.2). This allowed him to conclude that this culture was widespread and that there were two its variants, western and eastern, considered now as Alakul and Fyodorovka/Andronovo ceramics (Fig. 3.2). At the same time S.A. Teploukhov saw the connection of Andronovo culture with the previous Afanasievo culture of Southern Siberia, and M.P. Gryaznov wrote about the similarity of the western Andronovo sites to the Srubnaya culture of the Volga region.

In 1933, O.A. Krivtsova-Grakova excavated the Alexeevskoe settlement and burial ground on the Tobol River near Kostanay, where she discovered ceramics with ledges (western variant) and ceramics with applied cordons (Fig. 2.3). In fact, these complexes belong to different periods. But she believed that they were synchronous and reflected the late stage of the Andronovo culture with a mixture of two ceramic types. In this way, a path to the future determination of the latest sites, which now belong to the Final Bronze Age, was outlined. Additionally to this, ceramics were discovered in the Kozhumberdy cemetery excavated in 1930, which was intermediate in shape and ornamentation between the western and eastern variants. Since in her view the western variant evolved into complexes with cordoned decoration, she believed that this Kozhumberdy type was transitional to ceramics with the ledged shoulder of the western variant (Krivtsova-Grakova, 1948). At this time, she had already information about the excavations of K.V. Salnikov in the foreststeppe of the Transurals, near Chelyabinsk, where he discovered the cemeteries of the "eastern variant". It began to seem that initially this eastern variant had formed in the west, then spread to the east, and in the west the ceramic complex was evolving towards the formation of ware with the ledged shoulder, which was then supplemented by cordoned ware (Fig. 3.3).

In final form, this concept appeared in the writings of K.V. Salnikov, who in the 30s excavated mounds in the forest-steppe of the Transurals, in the Chelyabinsk and Kurgan regions. Here he discovered ceramics of both types, the "western" (in the Alakul cemetery) and the "eastern" (in the Fyodorovka cemetery) variants. As a result, he identified two stages of the culture, Fyodorovka and Alakul, and we still use this terminology. In addition, excavations of the Kipel settlement led him to conclude that Fyodorovka ceramics was earlier. Later, after excavations of the Zamaraevo settlement, he identified the Zamaraevo type of cordoned ceramics, which was similar to the ceramics that O.A. Krivtsova-Grakova found at the Alexeevskoe settlement. And these ceramics had a later chronological position. As a result, the first linear scheme of the Andronovo culture arose (Fig. 4.1), suggesting the genetic continuity of its stages at different times: Fyodorovka - Alakul - Zamaraevo (Salnikov, 1948, 1951).

This scheme quickly became popular, and ones tried to apply it for other territories. For example, in Central Kazakhstan, archaeologists, in general, adopted the scheme of K.V. Salnikov, assigning only local names to its stages: Nura (Fyodorovka) and Atasu (Alakul). At that time, they did not find an equivalent to Salnikov's Zamaraevo stage. The rich Begazi and Dandibay cemeteries with very specific ceramics, more comparable to the Karasuk and Irmen ware in Siberia, were identified there, and the last stage was called Begazi-Dandibay (Fig. 5; 6.1) (Margulan, Akishev, Kadyrbaev \& Orazbaev, 1966; Evdokimov \& Varfolomeev, 2002).

However, further in Eastern Kazakhstan, materials comparable to Salnikov's Zamaraevo materials were present, but there were no Alakul materials. Therefore, S.S. Chernikov (1960), generally agreeing with the Salnikov scheme, proposed a periodization with genetic continuity of the stages with local names: Ust'-Bukon' - Kanay - Malokrasnoyarka - Trushnikovo (Fig. 6.2). In the Ust'-Bukon' stage, he combined a series of chance finds that were not related to the

2 The cemetery near the village Andronovo was excavated in 1914 by A.Ya. Tugarinov, and even published by him, but it was A.S. Teploukhov, who also excavated cemeteries with similar material. M.P. Gryaznov participated in some of his excavations and listened to his reports (Bobrov, 2014, p. 268). 

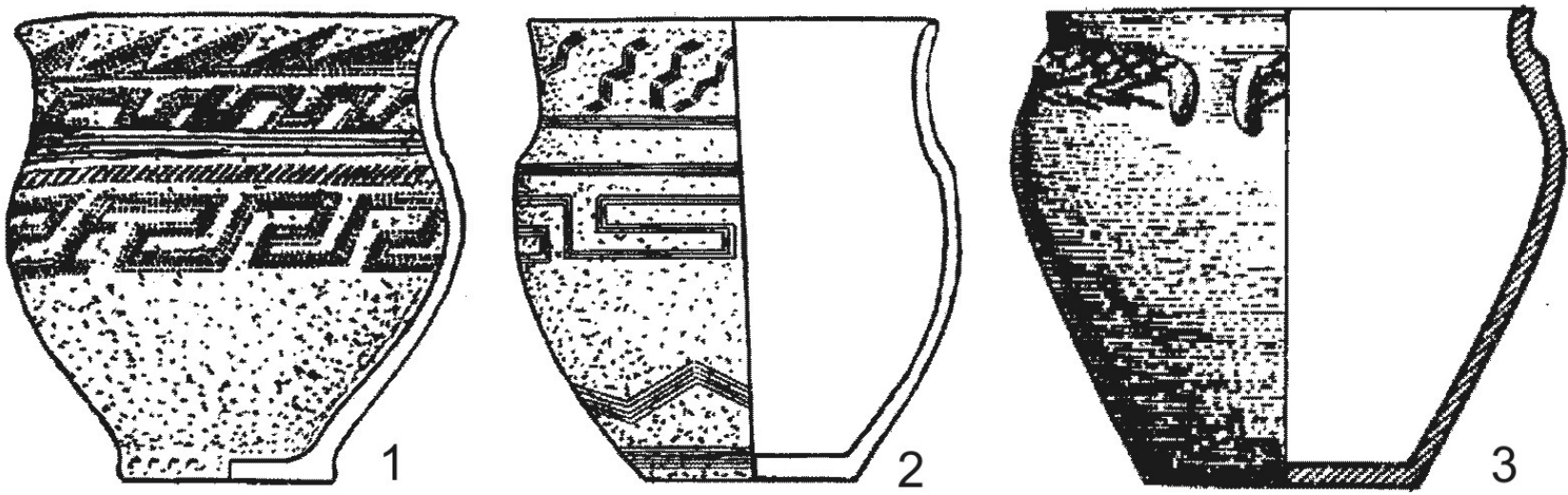

Figure 2: The basic principles of dividing the Andronovo ceramics in early studies: Fyodorovka (1 - cemetery of Putilovskaya Zaimka), Alakul (2 - cemetery of Baklanskoe) and Sargari (3 - Sargari settlement) ceramics (1, 3 - after Zdanovich, 1988; 2 - after Potemkina, 1985).
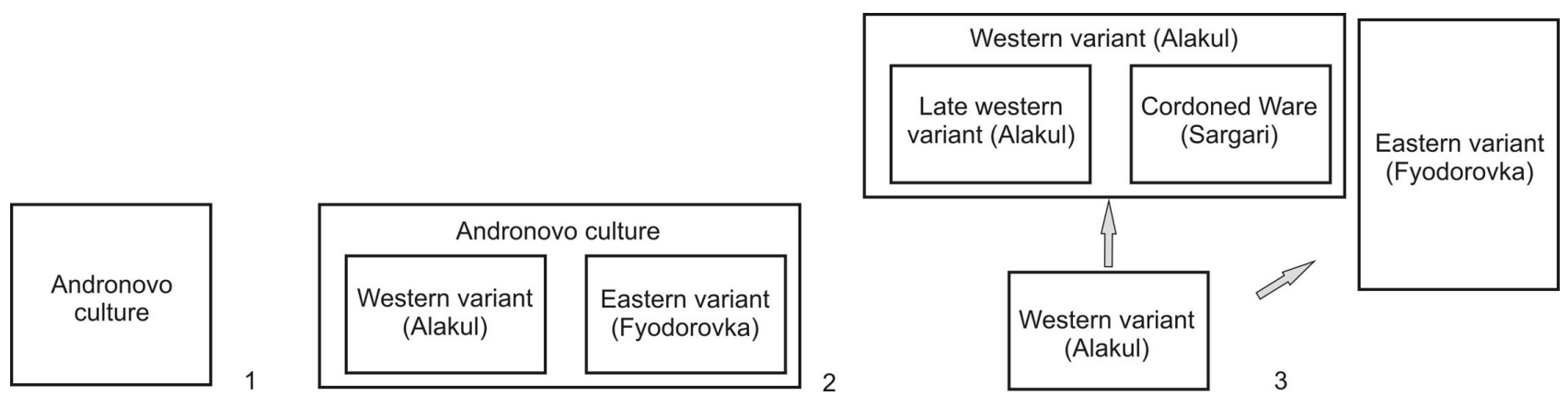

Figure 3: Schemes of cultural genesis in the period of formation of the Andronovo problem: 1) S.A. Teploukhov (1927), 2) M.P. Gryaznov (1927), 3) O.A. Krivtsova-Grakova (1948).

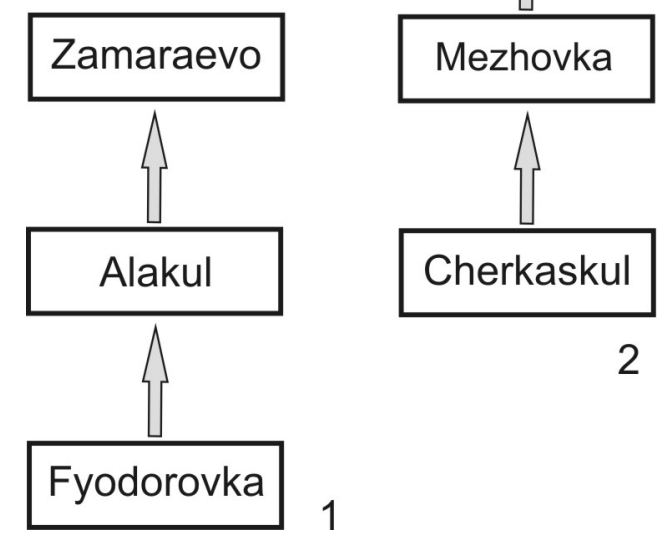

Figure 4: Scheme of Andronovo cultural genesis of K.V. Salnikov $(1948,1951)$ for steppe and forest-steppe (1) and for forest (2) areas. 

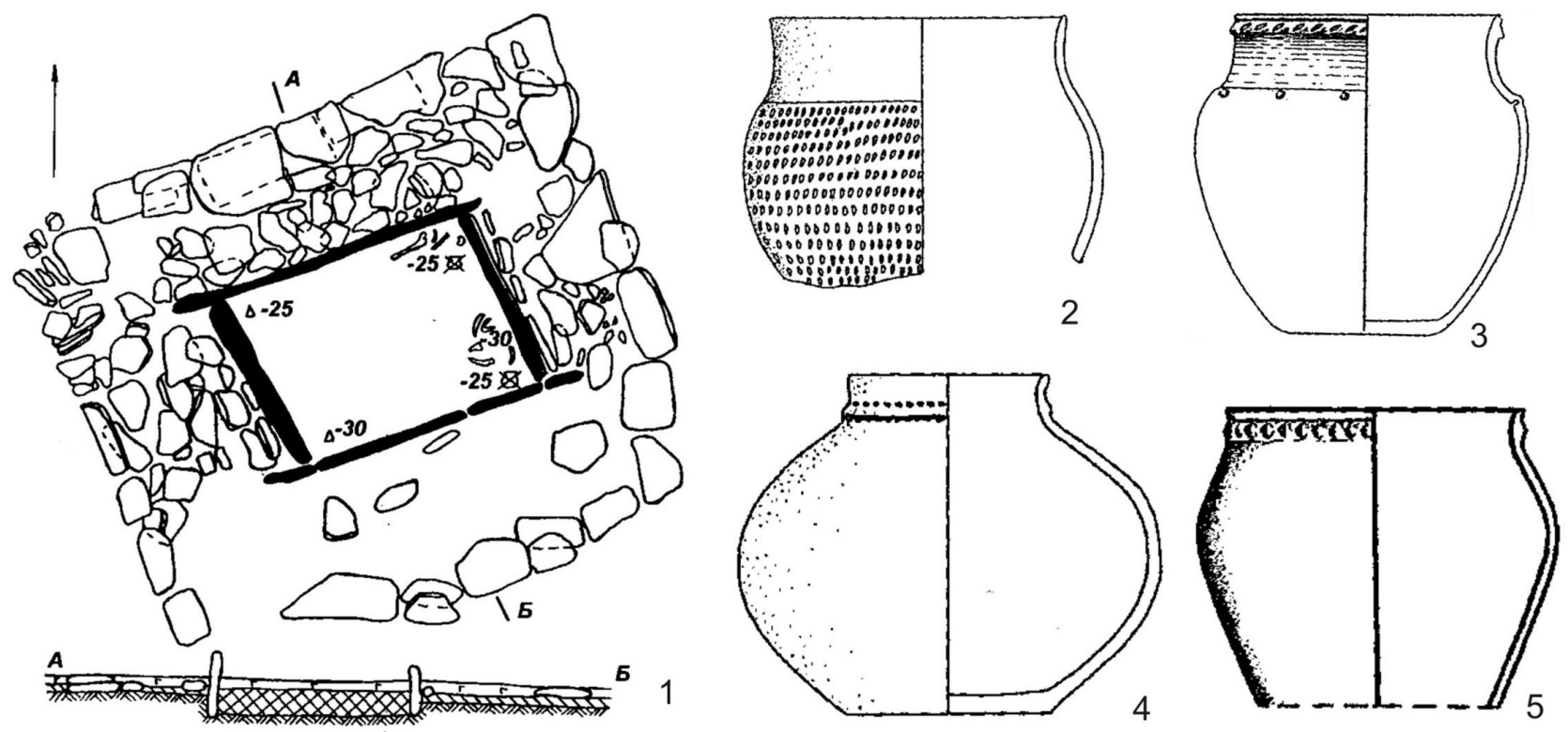

Figure 5: Begazi-Dandibay complexes: 1, 2, 4 - Dongal; 3 - Kent, 5 - Domalaktas (after Evdokimov \& Varfolomeev, 2002).

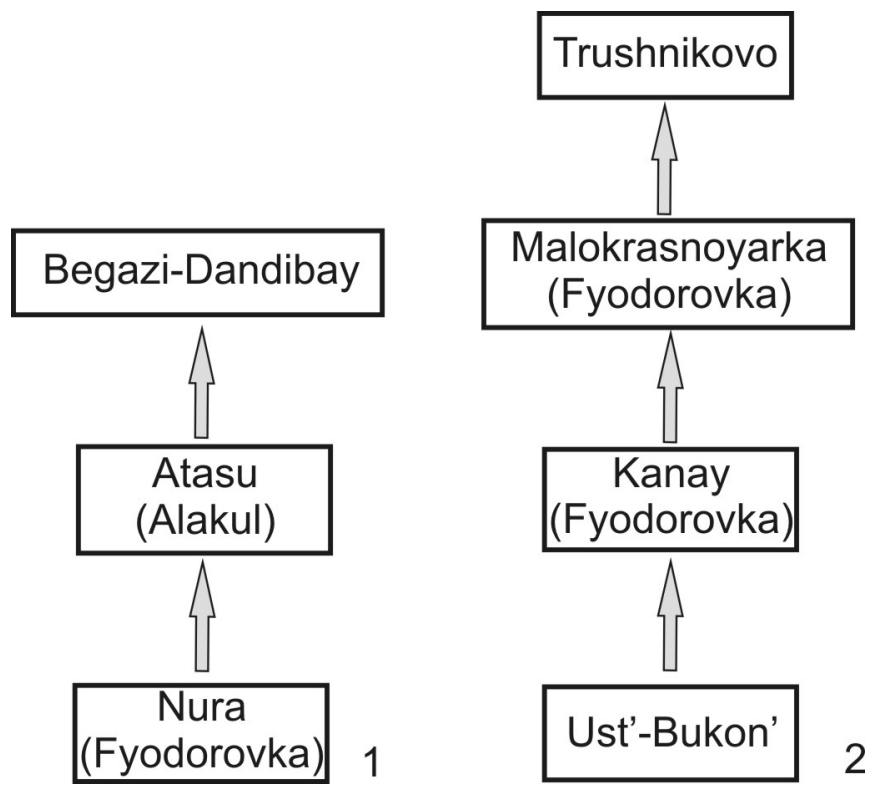

Figure 6: Schemes of Andronovo cultural genesis for Central (1) (Margulan et al., 1966) and Eastern (2) (Chernikov, 1960) Kazakhstan.

Andronovo culture, and the Trushnikovo ceramics are the cordoned complexes of the steppe Final Bronze Age, although with some local originality. A more complicated situation was with the materials of the Kanay and Malokrasnoyarka stages. They are comparable with the Andronovo in Southern Siberia and the Fyodorovka in the Transurals, but their division into two stages is rather doubtful. At that time, Fyodorovka settlement materials with cordoned ceramics, which were present in this culture from the very beginning were not yet known. Therefore, the presence of cordoned ceramics in the Fyodorovka layer of the settlement of Malokrasnoyarka S.S. Chernikov considered as a late sign indicating a transition to the Trushnikovo stage. This was a noticeable deviation from the Salnikov's scheme, which suggested a transition to cordoned ceramic complexes through the Alakul stage. 

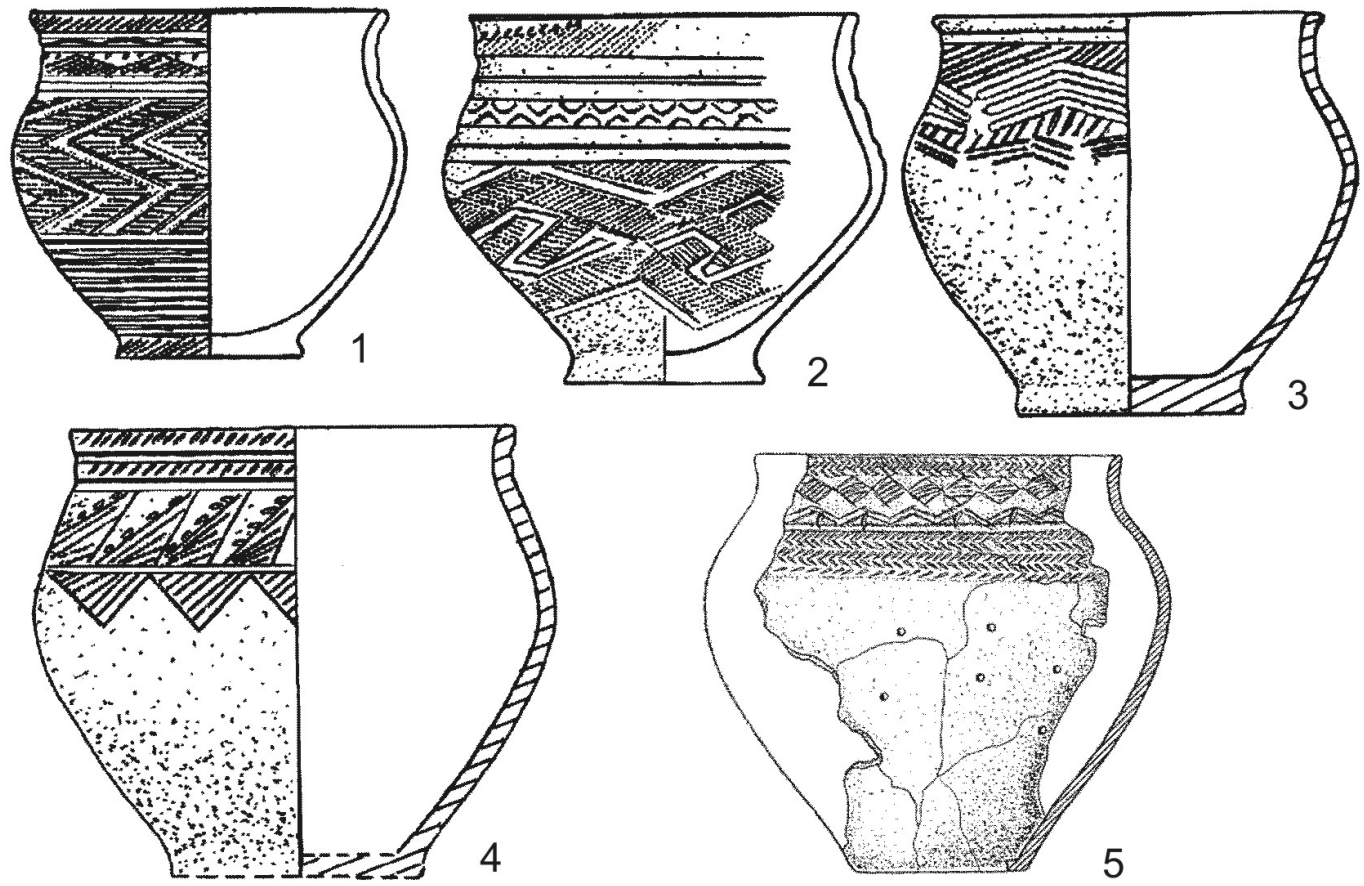

Figure 7: Cherkaskul (1, 2) and Mezhovka (3-5) ceramics: 1-4 - Priplodny Log, 5 - Kamyshnoe II (1-4 - after Zdanovich, 1988; 5 - after Potemkina, 1985).

Salnikov continued these works in the northern forest-steppe and in the forest zone, where he investigated a series of settlements and identified a new culture, Cherkaskul. As in the case of Andronovo, he divided it into three stages: Cherkaskul, Mezhovka and Beryozovoye (Fig. 4.2,7), although mirror synchronization did not exist here. The Cherkaskul stage was compared with Fyodorovka on the basis of the similarity of ceramics, and the Mezhovka and Beryozovoye with Zamaraevo. Salnikov believed that the Cherkaskul culture formed on the basis of the Ural Eneolithic; this forced him to suggest similar roots for Fyodorovka materials. But for the steppe Alakul sites, Salnikov also admitted the western influence of the Srubnaya culture (Salnikov, 1964, 1967).

Thus, we may characterize the first 20 years of the existence of the problem as the dominance of ideas about two synchronous lines in development of the Andronovo culture: Alakul and Fyodorovka, and for the next 20 years the idea of genetically linked complexes of different times dominated, where the Fyodorovka complexes were earlier. This concept of Salnikov seemed so convincing that even future supporters of the parallel existence of the Alakul and Fyodorovka cultures at that time wrote about Kozhumberdy as a transitional type from Fyodorovka to Alakul (Kuz'mina, 1964).

Because the main works were carried out in the Southern Transurals, and because this area had all types of Andronovo sites, this area became for many years the basic in Andronovo studies. This was especially characteristic of this early period of the long dominance of the Salnikov's scheme. But nothing is eternal.

\section{3 "Roller Coaster" of Andronovo Studies}

A decisive contribution to the rejection of the Salnikov's scheme was made by V.S. Stokolos (1972), who worked in Chelyabinsk in the 60s. His heritage is one of the many paradoxes of Andronovo studies. Everyone quickly accepted his criticism of the Salnikov's scheme, but his own scheme of the cultural genesis of the Ural cultures was not accepted, because in that atmosphere of simple decisions it was perceived as too complicated and confusing. Stokolos excavated many settlements and cemeteries in the Chelyabinsk and Kurgan regions and came to a conclusion that Cherkaskul ceramics coexisted with the Mezhovka ware, and there is no way to distinguish the Cherkaskul and Mezhovka stages, although there was a smooth evolution with a gradual growth of the Mezhovka ceramic type in the collections of 
Cherkaskul settlements. In an even more radical way, he dealt with the Andronovo culture. He demonstrated that Alakul and Fyodorovka ceramics in the settlements were simultaneous.

Moreover, he supposed that Alakul materials had appeared in the Urals somewhat earlier than Fyodorovka materials, although later they coexisted. He was the first to transform Salnikov's stages into two different cultures: Alakul and Fyodorovka. Since Alakul materials were absent in the east, due to the convincingness of his stratigraphic evidence, this idea of Stokolos was easily accepted. This fully corresponded to the prevalence of Alakul materials in the west, and Fyodorovka materials in the east, i.e., the paradigm with which the Andronovo problem began. The problem was in the Zamaraevo stage. In many settlements, ceramics with cordoned decoration was discovered in the same context as Fyodorovka ones. Therefore, Stokolos wrote about the synchronism of Zamaraevo and Fyodorovka ceramics. At that time, Fyodorovka settlements were not yet known, and no one knew that there was a settlement Fyodorovka tableware with cordons, which was absent in the burials. As such, all cordoned vessels were regarded as late. In addition, Stokolos pointed out that Zamaraevo ware is closer to Cherkaskul-Mezhovka and that it was different from cordoned complexes in the steppe. But the similarity of Fyodorovka and Cherkaskul ware, their frequent presence in the same layers, allowed him to synchronize them. For many years, these cultures were regarded as rather late chronological phenomena. Accordingly, the possibility of linking their genesis with Eneolithic complexes disappeared. According to Stokolos, there are no Fyodorovka strata in the Transurals, and the stay of the Fyodorovka people here was very short, which did not allow him to distinguish the Fyodorovka stage here. He divided the entire history of the Southern Transurals in the Bronze Age into two stages: Alakul and Zamaraevo (Fig. 8). Alakul was an autochthonous complex, although Stokolos did not indicate on what basis it had been formed. Zamaraevo type had no relations to Alakul. Fyodorovka people came to the Transurals from the east at the very beginning of the Zamaraevo stage. This stimulated the transformation of ceramic types with the formation of the Zamaraevo type and the close Mezhovka type. But Stokolos considered the Cherkaskul ceramic type as autochthonous; and this type had formed north of Alakul. As a result, Stokolos decided that Alakul and Zamaraevo should not be considered as the Andronovo complexes. He retained this right only for Fyodorovka monuments.

All this was too difficult to understand at that time, and his scheme was forgotten, but his idea of synchronizing Alakul and Fyodorovka was accepted quickly enough by everyone, and began to be applied in other territories, especially since the grounds for the earlier formation of Alakul appeared in other areas (Fedorova-Davydova, 1973; Kuz'mina, 1961; Smirnov, Kuz'mina, 1977). As a result, the scheme with the genetic continuity of the Andronovo culture was replaced by schemes with the parallel existence of cultures, which are now regarded as Andronovo.

The problem began to become more complicated with the advent of a new player in the arena, Petrovka culture (Fig. 9). It was discovered in Northern Kazakhstan by G.B. Zdanovich. The most striking feature of this culture was the presence of burials in chariots and fortified settlements - a feature that was previously known only in the Early Iron Age. The relation of this culture to Alakul and its earlier stratigraphic position were determined. Accordingly, it was concluded that Alakul was formed on the Petrovka basis (Zdanovich G.B., 1973, 1983). This led to the final refusal of Salnikov's scheme. At the same time, in the Southern Urals, the cemeteries of Noviy Kumak (Smirnov \& Kuz'mina, 1976) and Sintashta (Gening, 1975, 1977; Gening, Zdanovich, \& Gening, 1992) were investigated (Fig. 10). Sintashta was especially impressed with its complex of chariot burials and unusually rich funerary goods. The relatedness of these monuments to Petrovka was obvious, but also their difference. First of all, it was expressed in the presence of many features that have parallels in the Abashevo culture of the Volga region. Now these monuments are united under the name "Sintashta culture". Initially they got the name "Noviy Kumak", and this, from the point of view of terminology, is not the equivalent of the modern term "Sintashta", since the Petrovka complexes of Kazakhstan were also included in them. In this case, the similarity of these complexes to Alakul was also obvious, and they began to be considered as the basis of Alakul. Moreover, it was hypothesized that they had been formed as a result of migration to the Southern Urals of bearers of the Poltavka, Abashevo and Babino ${ }^{3}$ cultures from Eastern Europe (Fig. 11) (Smirnov \& Kuz'mina, 1977). Therefore, since that time, Salnikov's scheme has not been discussed by anyone and has become a purely historiographic phenomenon. This did provide an understanding of basis for the Alakul formation.

However, discussions on this issue have also arisen. They were caused by excavations of T.M. Potemkina of a series of settlements and burial grounds of the Alakul culture on the Tobol River in the Kurgan Region, and she suggested its

3 In the original work "KMK". Indeed the comparison was made not with proper Babino vessels, but with partly similar vessels of the late Catacomb culture 


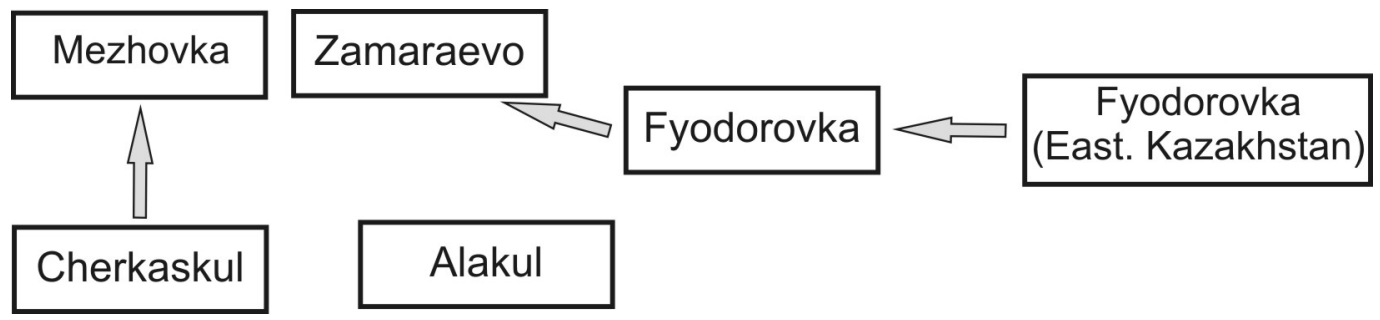

Figure 8: Scheme of Andronovo cultural genesis of V.S. Stokolos (1972).
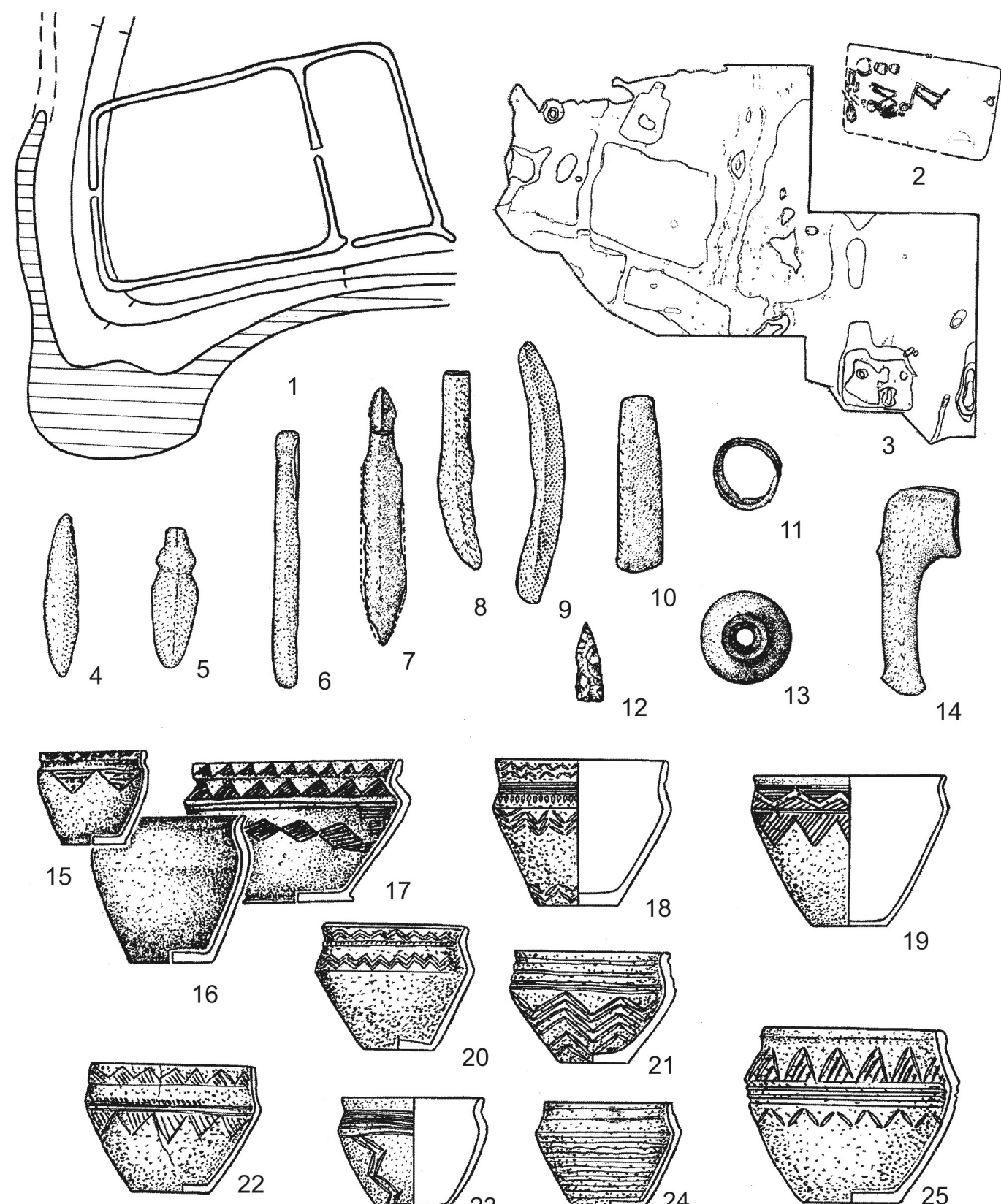

19

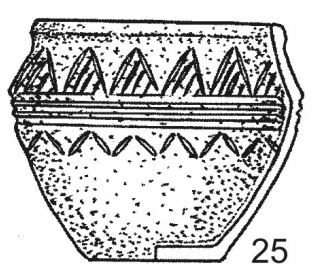

Figure 9: Petrovka culture: 1 - Petrovka II; 2, 15-17 - Bolshekaragansky cemetery; 3, 4-6, 8, 14, 18, 20, 22-24 - Kulevchi; 7, 10-13, 19, 21, 25 - Berlik; 9 - Kamyshnoe II (1 - after Zdanovich, 1988; 2, 15-17 - after Botalov, Grigoriev, \& Zdanovich, 1996; 3, 4-6, 8, 14, 18, 20, 22-24 after Vinogradov, 1982; 9 - after Potemkina, 1985). 


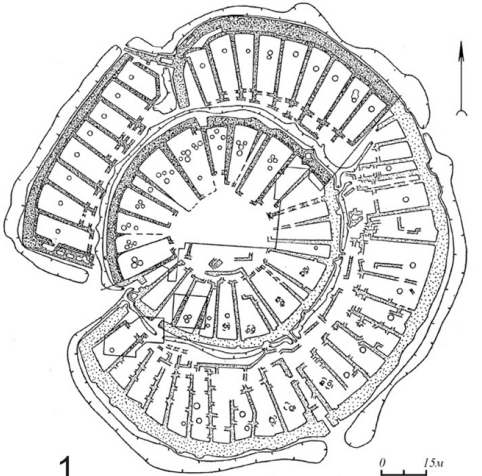

1
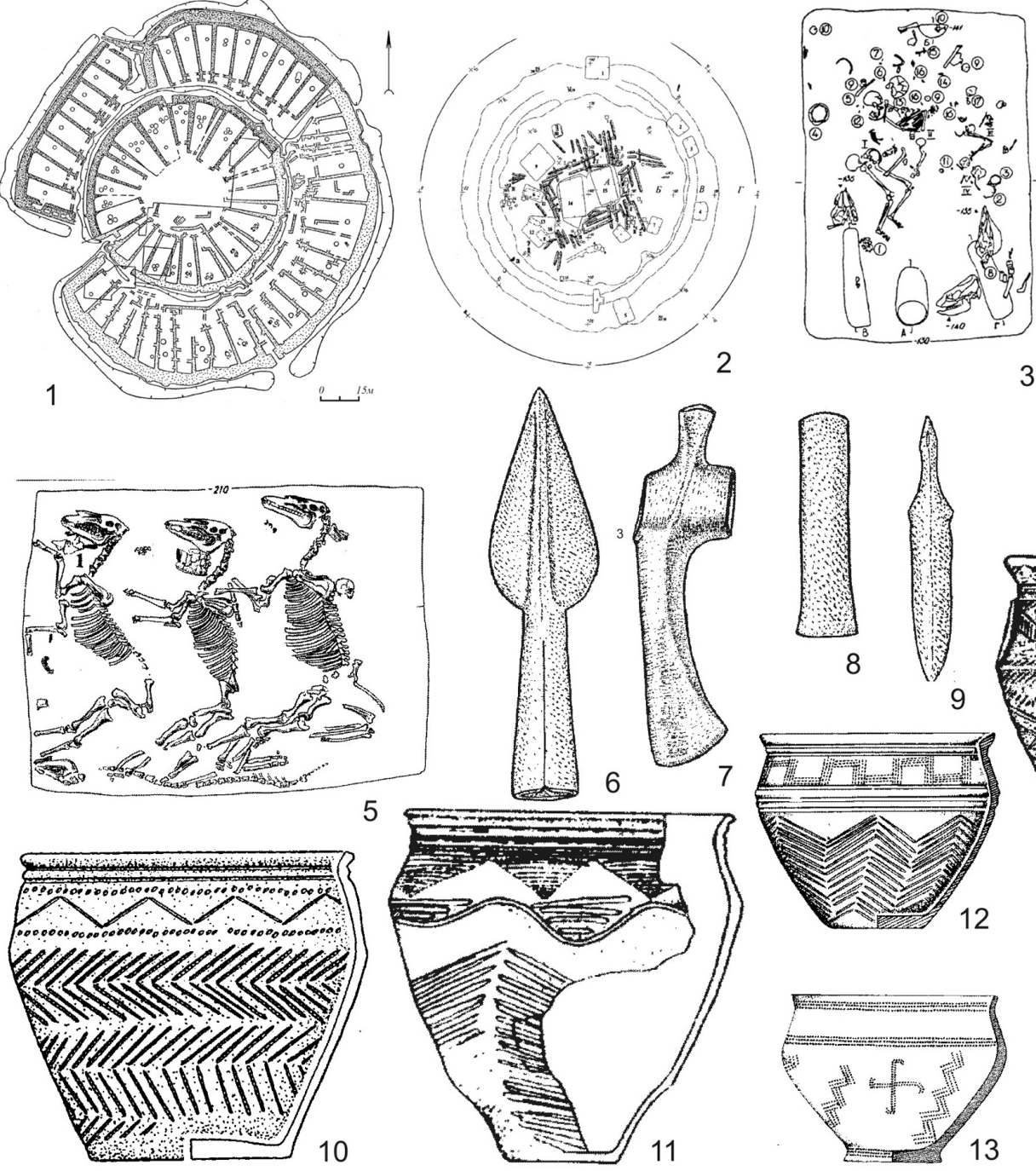

3
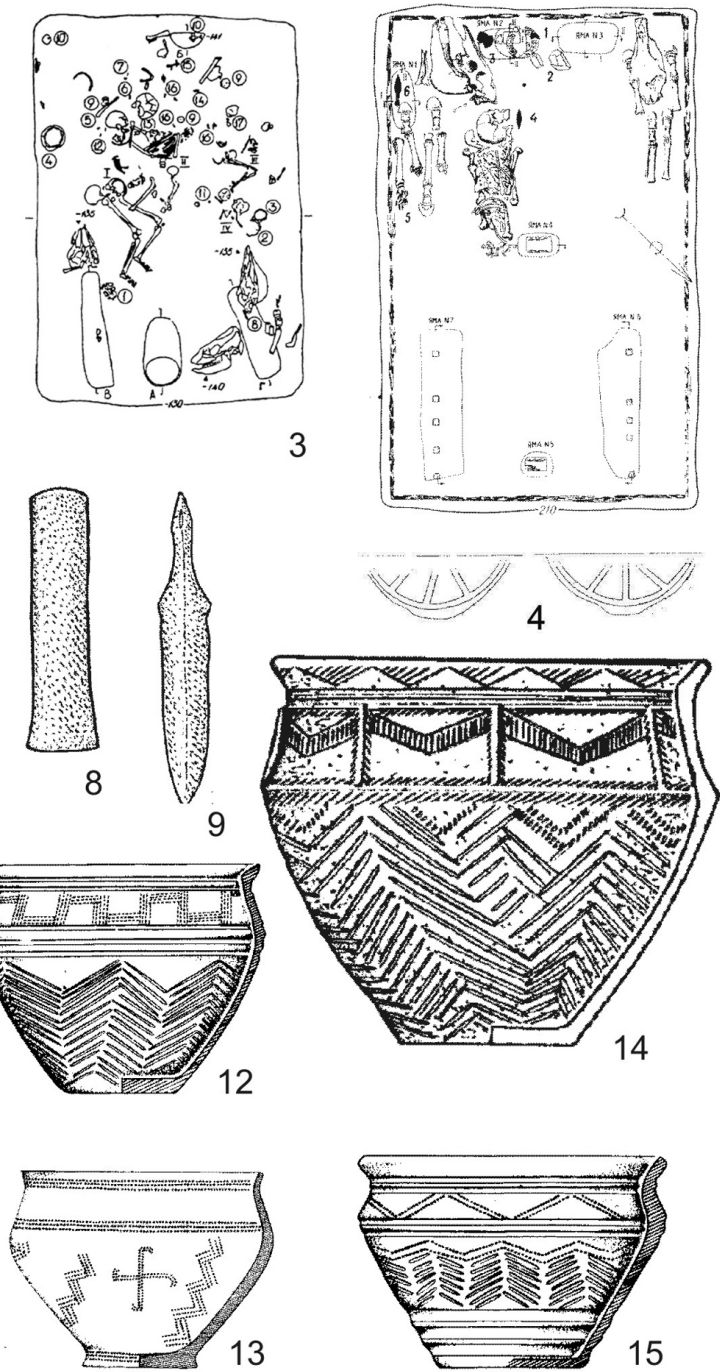

Figure 10: Sintashta culture: 1, 11 - Arkaim settlement; 2-8, 10-15 - Sintashta cemetery; 9 - Bolshekaragansky cemetery (1, 11 - after Zdanovich, 1997; 2-8, 10-15 - after Gening, Zdanovich, \& Gening, 1992; 9 - after Botalov, Grigoriev, \& Zdanovich, 1996).

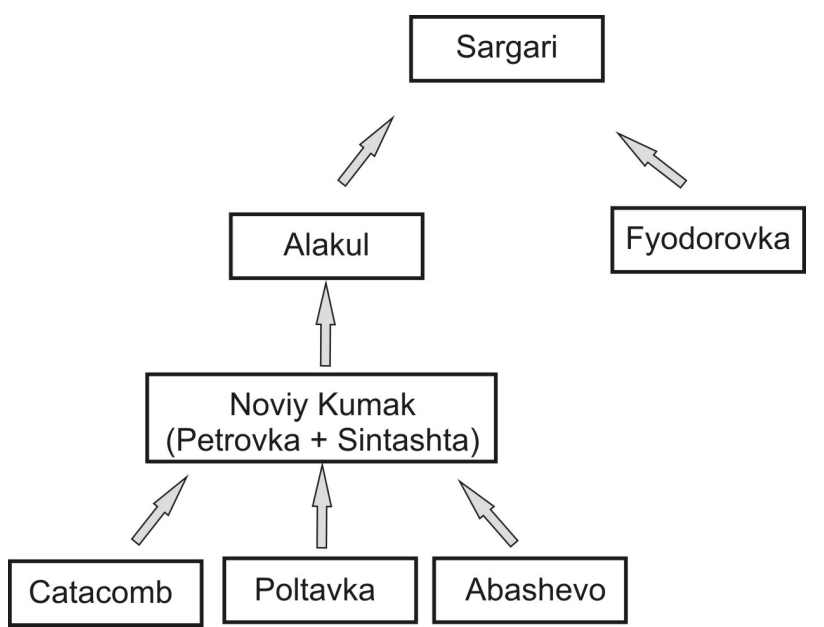

Figure 11. Scheme of cultural genesis of the Noviy Kumak type monuments with the parallel existence of Andronovo cultures (Smirnov \& Kuz'mina, 1977). 


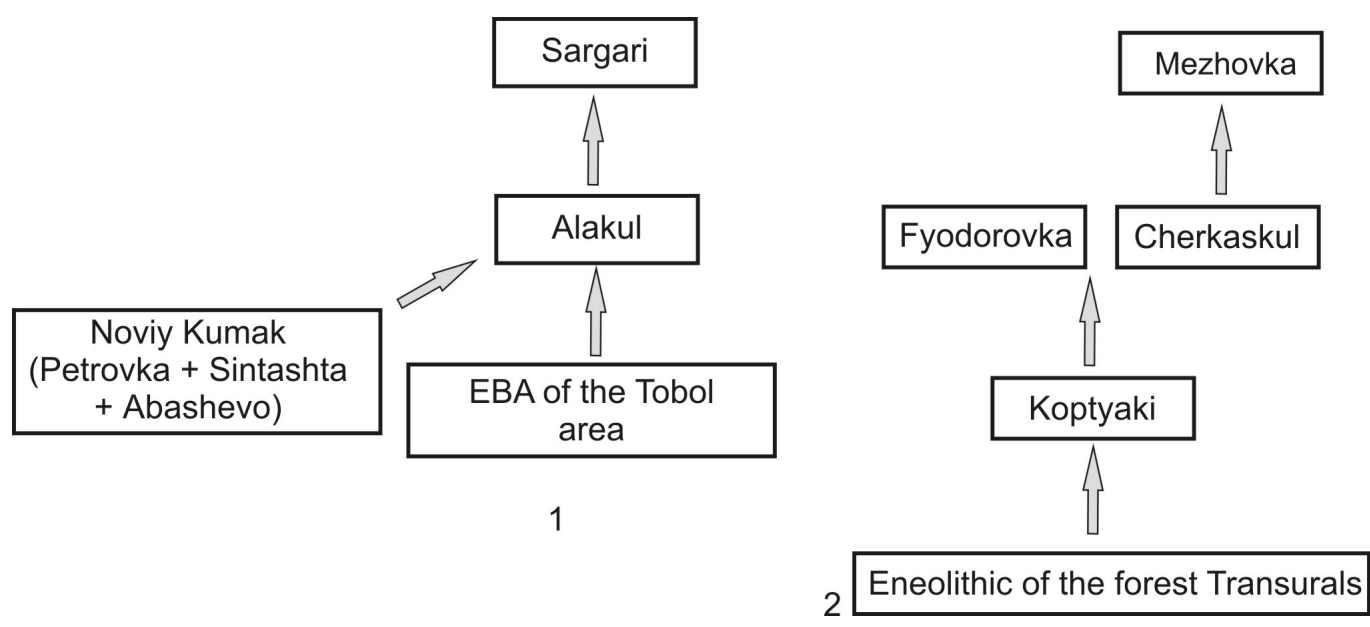

Figure 12. Scheme of Alakul culture genesis of T.M. Potemkina $(1983,1985,1994)(1)$ and Fyodorovka-Cherkaskul cultural genesis of M.F. Kosarev (1981) (2).

local roots in the forest-steppe Tobol area, although she allowed the previous Poltavka impulses from Eastern Europe (Fig. 12.1). And she considered the Fyodorovka and Cherkaskul complexes as late and alien (Potemkina, 1983, 1985). However, in reality, she also admitted some Abashevo or Noviy Kumak influences (Potemkina, 1994). At that time, this concept of "Noviy Kumak" was not too definite. The differences were only in the fact that she believed that the early Alakul complexes in the Tobol area precede Petrovka ones in that area.

Naturally, this whole situation raised the question of the relationship between Alakul and Fyodorovka. They began to be considered as independent synchronous formations, but it was completely unclear where to look for sources of the Fyodorovka culture. Nevertheless, everyone saw the stylistic similarity of Alakul and Fyodorovka ware. Therefore, they were united as two separate cultures within the framework of the Andronovo cultural-historical commonality. This concept has never been seriously worked out and never existed as a truly scientific concept. As a result, it was used to describe mutually exclusive situations. The term "Andronovo culture" sometimes continued to be used, but it was rather a tribute to tradition and habit, since no one since that time has allowed the possibility of considering all these complexes within one culture.

During this period, the problem of the origin of Fyodorovka culture seemed insoluble. It was a strange culture, with a lot of burials, with an admixture of ceramics in settlements of other cultures, but with the absence of its own settlements. There were attempts to find its origins in the Eneolithic sites of Central Kazakhstan (Kuz'mina, 1994, p. 118), but in reality, there were no comparable materials there. Therefore, only the Chernikov's scheme for Eastern Kazakhstan remained relevant, where the origin of the Fyodorovka culture (in the Ural terminology) was seen in complexes of the Ust'-Bukon' type. There was also an understanding of the similarity of Fyodorovka and Cherkaskul ceramics; therefore, there were ideas about the origin of Fyodorovka culture somewhere in the Urals, although there was no concrete evidence in favor of this. Everything was limited to talking about the traditions of the "Ural combed geometrism", which was characteristic of the local Eneolithic, Fyodorovka and Cherkaskul cultures. This was hindered by the chronological gap between the Eneolithic and Fyodorovka-Cherkaskul materials. After the works of Stokolos, these cultures were dated to a relatively late time. An attempt to solve this problem was outlined by the works of L.P. Khlobystin (1976, pp. 58-62), but above all of M.F. Kosarev (1981, pp. 80, 141), who tried to connect these Eneolithic traditions through the Koptyaki ceramic type (Fig. 12.2). This is a relatively rare type of the forest area, it has a lot of Alakul features, but some archaeologists also mentioned Abashevo and Petrovka features, which do not correspond to reality, but it was necessary to avoid contradictions when comparing this scheme with the Alakul line of development.

Like other versions of the Fyodorovka origin, this was not at all convincing, which became an important background for a new paradigm shift in Andronovo studies. This change began with the work of N.A. Avanesova (1991), who came to the conclusion that the Alakul metal was earlier than the Fyodorovka metal, although in reality we are talking about two complexes that are not closely related to each other. Here, as elsewhere in this article, the dates of the most important publications are given, which do not quite correspond to the dates of birth of the ideas discussed at various 


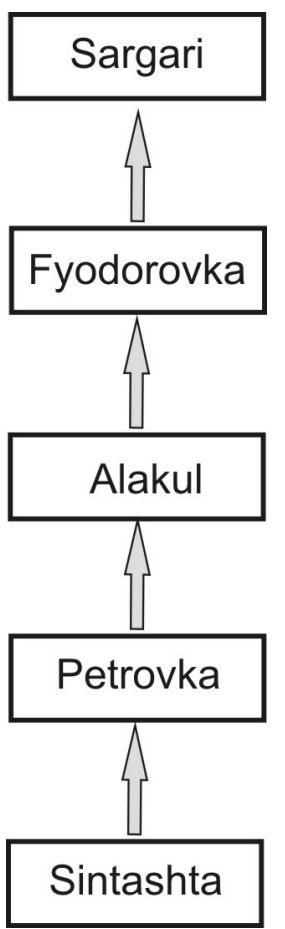

Figure 13: Scheme of G.B. Zdanovich $(1973,1988)$ with the genetic continuity of the Andronovo cultures.

conferences, meetings, etc. It was a turbulent time, and I, as a student, was lucky enough to see all this at the $2^{\text {nd }}$ Andronovo Conference in April 1980. Therefore, it is sometimes difficult to determine the specific author of a particular idea. Certainly, for subsequent events G.B. Zdanovich had his own reasons and ideas, but his final formulation was prompted by communication with N.A. Avanesova. Nevertheless, it was he who became the main and most convincing author of this theory.

Zdanovich became the founder of the new theory in the Andronovo studies. In Northern Kazakhstan, he discovered monuments of the Amangeldy type, which combined Alakul forms with Fyodorovka ornamentation. Therefore, the idea arose that these monuments, as well as monuments of the Kozhumberdy type, discovered earlier by O.A. KrivtsovaGrakova, reflect the evolution of Alakul culture to Fyodorovka. But this was only a potential opportunity, which should be confirmed by other data. And they appeared after the discovery of the Bishkul ceramic type, which was considered as a settlement Fyodorovka ware. The continuity of this Bishkul type with subsequent complexes with cornoned ceramics was also proposed; and the later position of Fyodorovka ceramics relative to Alakul ceramics in the settlements of Northern Kazakhstan was demonstrated stratigraphically. In addition, the sites of the Final Bronze Age were studied, which were named first "Ilyinka", then "Sargari". It was shown that these sites are different from Zamaraevo type of Salnikov and Stokolos, and they determine the specifics of this period in the steppe zone. At the same time, T.M. Potemkina (1975) excavated similar sites in the Transurals, and she also showed their difference from Zamaraevo and a later position relative to Alakul. But she believed that the name of the culture should be "Alexeevskoye", where this steppe ceramics with cordons was found for the first time. True, unlike the Alexeevskoye settlement, where there is Alakul ware, the Sargari settlement is a complex without admixture of ware of other cultures. Therefore, in Russian literature, the culture is usually named "Sargari" or "Sargari-Alexeevskoye". The term "Alexeevskoye" is almost never used.

As a result, a new scheme of the sequential genesis of Andronovo cultures was constructed, in which, in comparison with the previous scheme of K.V. Salnikov, Alakul and Fyodorovka cultures exchanged places. The sequence of cultures was determined: Petrovka - Alakul - Fyodorovka - Sargari (Fig. 13), and all of them began to be considered as cultures of the Andronovo cultural-historical commonality (Zdanovich G.B., 1973, 1984, 1988). Thus, this concept obtained a completely different meaning. More precisely, it simply lost sense, since it is very problematic to speak in terms of "commonality" about genetically consistent formations. Nevertheless, this did not bother anyone, since this concept 
was not used as a scientific tool, the researchers operated with specific cultures, and the term "Andronovo commonality" was used of habit, as the term "Andronovo culture" used before.

Against the background of the already obvious connections between the Alakul complexes with the Sintashta and Petrovka ones, against the background of the absence of even minimal opportunities to find roots of Fyodorovka culture, this scheme very quickly gained popularity, and for many years became dominant in Andronovo studies. Its main advantage was logic and simplicity. It seemed that over time more facts would appear that would show this continuity between the various stages proposed by Zdanovich. In particular, the work of N.B. Vinogradov at the settlement of Kulevchi III made it possible to distinguish the Kulevchi type, which was considered as a transition between Petrovka and Alakul (Vinogradov, 1982). Problems of this type were subsequently often debated, and then N.B. Vinogradov began to consider it as a type of the high Petrovka phase. But he changed his understanding of Petrovka culture in general, proposing to consider it as early Alakul culture, and he proposed to name the Petrovka monuments of Northern Kazakhstan "Sintashtoid” (Vinogradov, 2011, pp. 102-108, 144).

At this time, the identification of the Kulevchi type created hopes that gradually other shortcomings of this new scheme of the genetic sequence of Andronovo cultures would be eliminated. In that situation, this, indeed, was the best solution, and most researchers began to adhere to it. This could not be in its full form, but the overwhelming majority agreed with many positions of this scheme. These ideas were strengthened after G.B. Zdanovich undertook extensive research on Sintashta fortified settlements and cemeteries in the Southern Transurals (Gening, Zdanovich, \& Gening, 1992; Zdanovich G.B., 1997). Initially, synchronization of the Petrovka and Sintashta monuments was admitted (Kuz'mina, 1986; Zdanovich G.B., 1988, p. 132). His research and works of N.B. Vinogradov showed that in the steppe Transurals the Sintashta culture preceded the Petrovka culture, thus being the basis for its formation (Vinogradov, 1995, 2011, p. 138; Zdanovich \& Batanina, 2007). Thus, another link, "Sintashta - Petrovka", was added to this genetic chain, which strengthened confidence in the scheme as a whole (Fig. 13).

However, a question remained about the origin of the earliest culture, Sintashta. For many years that have passed since the hypothesis was published about the formation of Sintashta as a result of migration from Eastern Europe (Smirnov \& Kuz'mina, 1977), no works appeared in which this hypothesis would be based on well-developed typological series, although this hypothesis was accepted by absolutely everyone. Against the background of the availability of many well-published materials, this was rather strange. Moreover, with the accumulation of information on the Sintashta culture, Potapovka monuments in the Volga region and Sintashta monuments in the west of the Southern Urals were investigated in which these Eastern European features can be found (Vasiliev, Kuznetsov \& Semenova, 1995; Tkachev, 2007), but there is no brightest feature of this culture, fortified settlements. In the core area of the culture in the Transurals, we only find a few Eastern European inclusions, though they did not determine the originality of this culture. Unexpectedly, parallels to most features of Sintashta culture were found in Syro-Anatolia and Transcaucasia (Figs. 14, 15), which allowed the hypothesis to appear that it was formed as a result of migration from the Near East, and along the route of this migration to the Urals it included also some Eastern European components (Grigoriev, 1996, 2002).

This problem does not change anything in the Andronovo problem, where the dominance of Zdanovich's new theory about the linear development of genetically related Andronovo cultures remained. Nevertheless, at the same time there were many supporters of synchronization of Alakul and Fyodorovka (Kosarev, 1981; Potemkina, 1985; Kuz'mina, 1986; Bobrov, 1993; Grigoriev, 2000; Korochkova \& Stefanov, 2001; and others). The main arguments in favor of this idea were the contrast of Alakul and Fyodorovka materials in the west and a rather standard situation of the presence of ceramics of both types in the same layers. There was no unity within this direction, since various approaches to the cultural genesis of individual cultures were debated. As a result, for many years the essence of the Andronovo problem was precisely this opposition: some of the authors believed that within the framework of the Andronovo cultural-historical commonality there were two successive genetically related cultures (Alakul and Fyodorovka), while others believed that they were synchronous cultures, and some similarity of their ceramic complexes was caused by intensive contacts. In accordance with this last position, the Kozhumberdy and Amangeldy types were considered not as transitional, but as contact ones. Moreover, the Amangeldy type contains earlier Petrovka features, and some ceramic forms are indistinguishable from Petrovka, which is excluded for the type that was formed in the final Alakul period and casts doubt on the possibility of forming the Fyodorovka culture on the Alakul basis. This creates a feeling that the contact of the Alakul and Fyodorovka people occurred at a time when Petrovka culture still existed (Grigoriev, 2000, p. 337; 

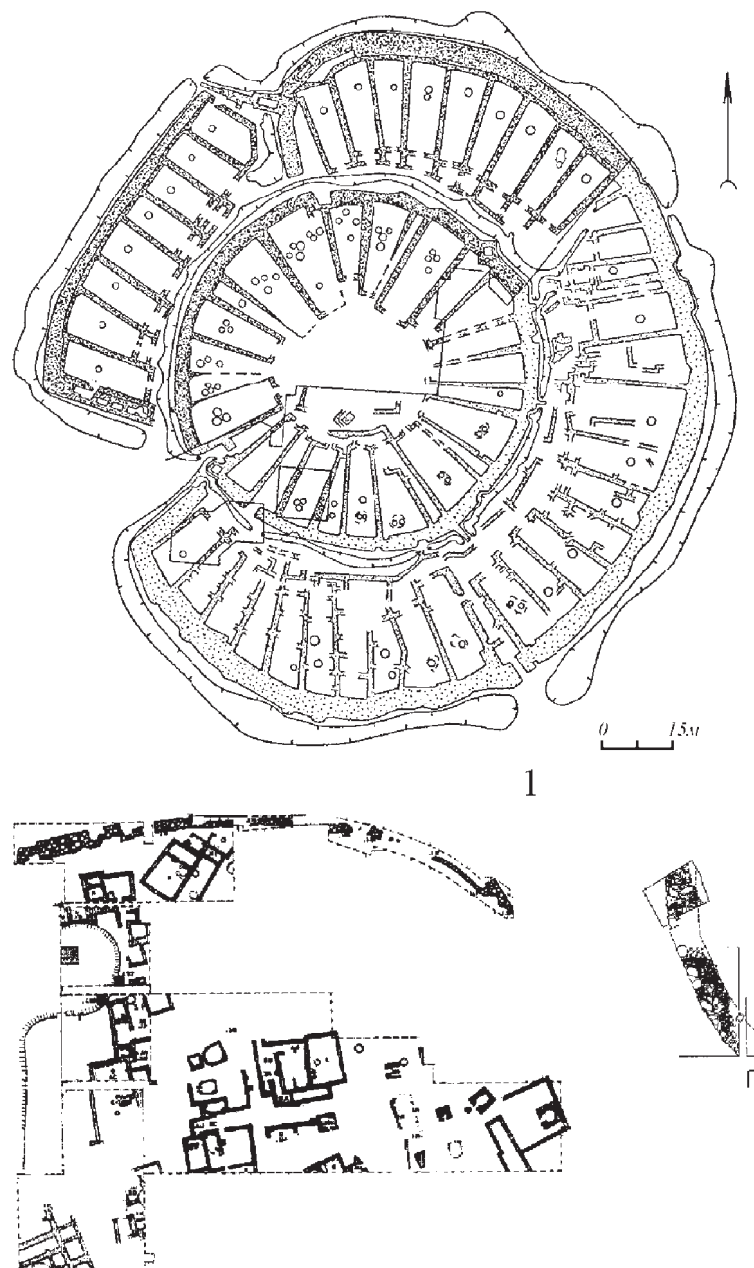

D.

霓

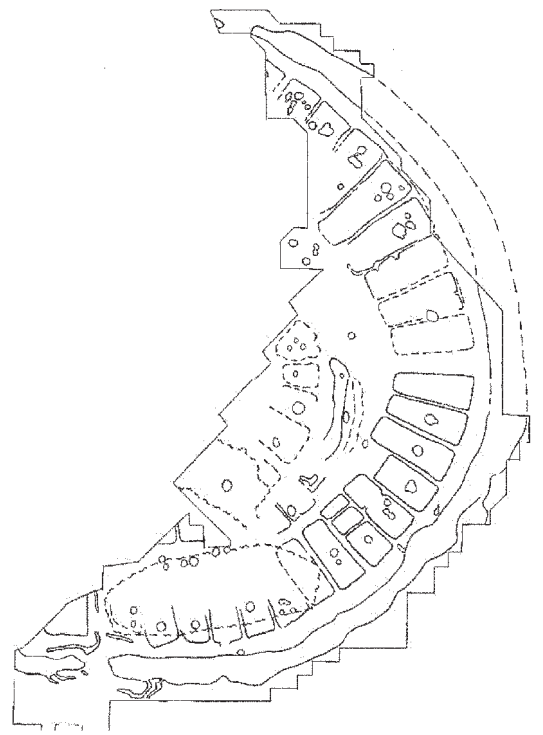

2
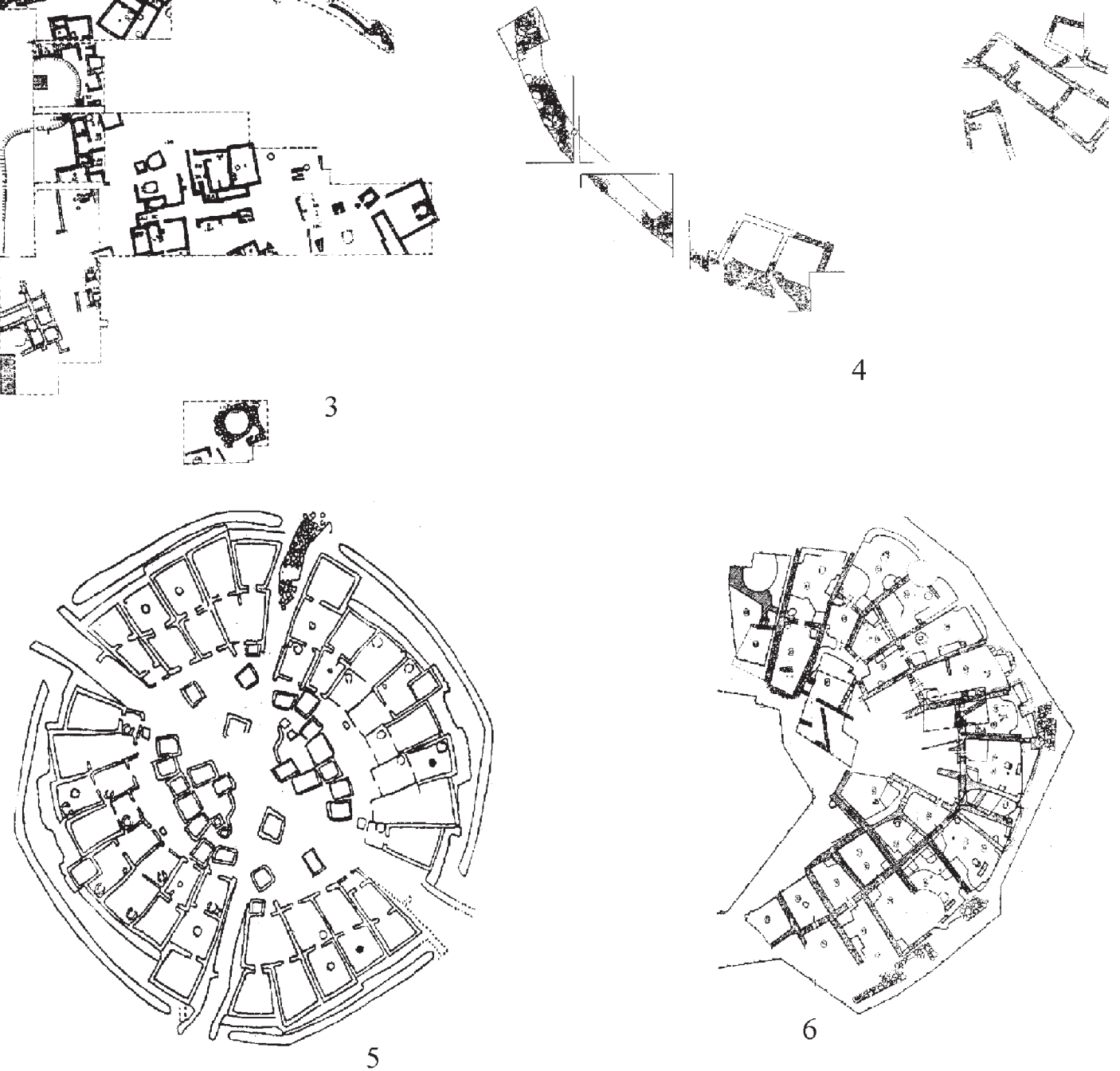

Figure 14: Sintashta fortified settlements $(1,2)$ and their analogues in Anatolia (3-6): 1 - Arkaim, 2 - Sintashta, 3 - Tüllintepe; 4 - Heraion; 5 Demircihöyük; 6 - Pulur (1 - after Zdanovich, 1997; 2 - after Gening, Zdanovich, \& Gening, 1992; 3-6 - after Korfmann, 1983; Grigoriev, 2002). 

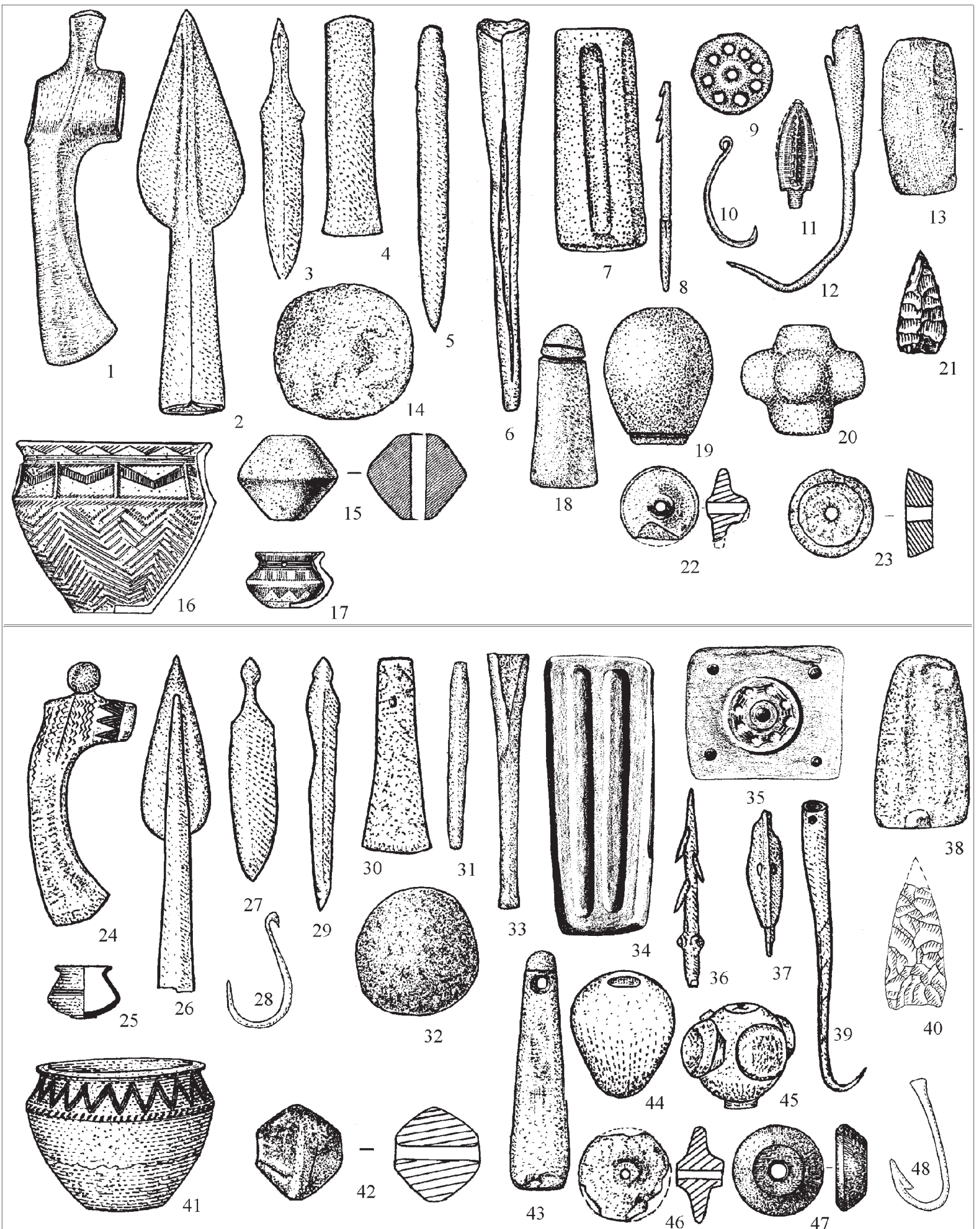

40

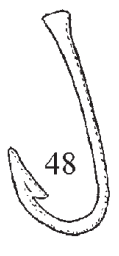

Figure 15: Objects of Sintashta culture (1-23) and their analogues in the Middle East and the Caucasus (24-48): 1, 3, 4, 10, 11, 13, 14-19, 21-23 - Sintashta; 2, 20 - Kamenniy Ambar V; 5, 6 - Tyubyak; 7-9, 12 - Arkaim; 8 - Bolshekaragansky; 24 - Kumbulta; 25 - Tell Mardikh; 26 - Esheri; 27 - Ur; 28, 45, 48 - Susa; 29, 30 - Gaza; 31 - Calicaköyü; 32, 38, 42, 43 - Demircihöyük; 33 , 37 - Alaca Höyük; 34 - MalatyaArslantepe; 35 - Kültepe (Karum); 36 - Tell ed-Dab’a; 39 - Kirovokan; 41, 46 - Hama; 44 - Nahal Mishmar; 47 - Arich (after Grigoriev, 2002). 
2006, pp. 215-217; Stefanov \& Korochkova, 2006, p. 122). But in the absence of real sources for Fyodorovka culture, the situation looked stalemate.

It is necessary to mention one more important circumstance. Alakul materials in the vast territory of the Urals and Kazakhstan, of course, show a certain variability, which makes it possible to distinguish territorial variants. But in general, they fit into the general Alakul stereotype. The situation with Fyodorovka culture is more complicated. Its complexes demonstrate almost identical ceramics in different territories, but a very contrasting funeral rite. The Fyodorovka culture of the Transurals is represented by burials with cremation, and on the Yenisei, mainly with inhumation, in the presence of mixed complexes in Kazakhstan. The paradox is that Alakul burials are represented exclusively by inhumation, and Alakul culture is completely absent in Southern Siberia. As a result, the term "Fyodorovka culture" used in the Urals and Kazakhstan is not applicable in Siberia, and Siberian archaeologists prefer to use the term "Andronovo". And therefore, the term "Andronovo cultural-historical commonality" is better not to use (Bobrov, 1993; Grigoriev, 2000). Due to the absence of Alakul complexes in Siberia, the use of this term there does not pose any particular problems, although one can meet the use of the term "Fyodorovka" to designate the ceramic type. On the other hand, in the western part of the Andronovo area, where both Alakul and Fyodorovka sites are represented, archaeologists rarely use the term "Andronovo", since its use makes it impossible to understand what complexes are meant, Fyodorovka or Alakul. It is used more often as a kind of figurative expression to refer to processes in the Late Bronze Age in general. Therefore, there were even proposals to use several terms for these materials: "Andronovo" in Southern Siberia, "Kanay" in Eastern Kazakhstan, "Nura" in Central Kazakhstan and "Fyodorovka" in the Transurals (Korochkova \& Stefanov, 2001). But the mechanism for describing the process as a whole disappeared, and I, for example, use the term "Fyodorovka", understanding its certain flaw. Unfortunately, even in such a simple question of terminology, there is no correct and unambiguous solution today.

\section{New Problems and Approaches in the Andronovo Studies}

All these studies revealed new paradoxes. On the one hand, Fyodorovka settlements were discovered in Southern Siberia, Eastern Kazakhstan and in the south of the forest zone of Western Siberia (Chernikov, 1960; Bobrov \& Mikhailov, 1989; Stefanov \& Korochkova, 2000; Tkacheva \& Tkachev, 2008; Kiryushin, Grushin \& Leontieva, 2016). Their peculiarity was that in them the proportion of vessels with the magnificent specific Andronovo combed decoration was small. Ware decorated with simple carved or stamped ornaments dominated there. And a part of the vessels had a cordon, which gave hope that this would connect these ceramics with subsequent cordoned ceramics in the steppe and foreststeppe (Fig. 16). But in most areas where bright Fyodorovka burials were known (Central and Northern Kazakhstan, the Transurals), Fyodorovka settlements have not been identified until today, despite intensive works over the past decades. In the Transurals, this led to the conclusion that the Fyodorovka stage was absent there, despite the fact that there is a series of funerary monuments and the presence of Fyodorovka ceramics in settlements of other cultures. Fyodorovka culture even began to be considered as a subculture within the Alakul culture (Korochkova \& Stefanov, 2001; Stefanov \& Korochkova, 2004, p. 64, 2006, p. 125). I criticized this point of view, based on the fact that in order to preserve cultural stereotypes, an area is needed where these stereotypes compactly existed (Grigoriev, Petrova, Pleshanov, Gushchina, \& Vasina, 2018, p. 195). On review this criticism was unjust, since colleagues did not write about Fyodorovka culture in general, but about Fyodorovka culture in the Transurals. We see that it was a repeated on a new level the point of view of V.S. Stokolos, although it happened completely independently, after many years.

After all of this time, there was no opportunity to determine the place of origins of Fyodorovka culture. There are suggestions about its origin in the Tobol area (Zakh, 2014), but they are not substantiated. All other authors agree that in the Transurals this culture came from Eastern Kazakhstan. Thus, the sequence of development of Fyodorovka culture shown for this region (Tkacheva \& Tkachev, 2008, pp. 247-250) merits attention, but does not answer the question of origins, since it is not connected with previous complexes. In this culture there are inclusions of pottery from the south of Central Asia, a part of the metal forms and metallurgical technologies indicate possible impulses from the Middle East. This led to the conclusion about the migration influenced its formation (Grigoriev, 2002, pp. 235-245; Bobrov, 2014, p. 276). However, this supposition also does not yet have a sufficient typological justification. In the settlement ware, we can distinguish some local Siberian features in the form of horizontal carved herringbone design, but this did not 

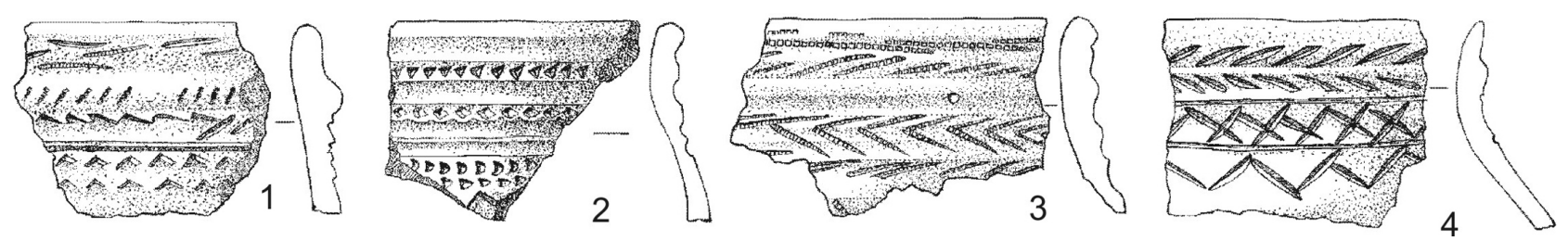

Figure 16: Cordoned ceramics of Fyodorovka culture $(1,2)$ and its transformation into Mezhovka forms $(3,4)$ in the Transurals: 1 - $U$ Spasskogo Mosta, 2, 4 - Miasskoe, 3 - Kizilskoe (after Grigoriev, 2000).

determine the main cultural features. There are small inclusions in which the Poltavka, Abashevo, Catacomb, Petrovka and Sintashta features are vaguely guessed (Grigoriev et al., 2018, p. 194). But all this is also a small admixture to the already established Fyodorovka stereotypes. Therefore, most likely, some local component took part in the formation of the culture, there were some impulses from the west, and some impulse from the south was also possible. But all this has not yet been practically studied. Three things are obvious: 1) the problem of the final formation of the Fyodorovka/ Andronovo culture should be solved somewhere in the regions of Eastern Kazakhstan and Western Altai, 2) this culture could not be formed only on the local base of Eastern Kazakhstan or Southern Siberia, 3) in the Urals and in the south of Western Siberia the bearers of this culture came from the east, where Fyodorovka culture formed. And today this is the biggest mystery of Andronovo studies.

In the west of the Andronovo area, we have a number of problems too. As stated above, after the work of G.B. Zdanovich, who proposed the new scheme for the linear development of genetically related Andronovo cultures, most colleagues accepted it. However, even its opponents, including myself, did not accept it only in that section, which deals with the core problem of Andronovo studies, the relation of Alakul and Fyodorovka cultures. The early genetic line, "Sintashta - Petrovka - Alakul", initially did not cause any doubts. The first such doubts were expressed by A.V. Matveev, who excavated the Alakul cemeteries of Chistolebyazhye and Khripunovskiy in the north of the forest-steppe Tobol region and received very early radiocarbon dates that fell into the Sintashta interval (Matveev, 1998, pp. 359-373). Because of this no one took these dates seriously for a long time. However, a subsequent analysis of Alakul materials led to a conclusion that they are more comparable with Sintashta than with Petrovka. Therefore, the Alakul culture formed on the Sintashta basis, at the end of this culture, simultaneously with the Petrovka culture (Matveev, 1998, pp. 348-352; Grigoriev, 1999, pp. 145, 146, 2000, pp. 310-313). This was partly compatible with T.M. Potemkina's opinion on the origin of the Alakul culture in the forest-steppe Tobol region, although we, unlike Potemkina, did not see the local Early Bronze Age component in this origin.

Notablly, there was one paradox: in the forest-steppe Transurals, north of the Sintashta area, there are no sites that we can date to the Sintashta period, but there are early Alakul sites. An explanation for this paradox was found after excavations of the early Alakul settlement of Mochishche in the forest-steppe Transurals (Grigoriev et al., 2018). Alakul ceramics reliably lay in the same layers with Petrovka, and Petrovka ceramics there had more Sintashta features, rather than features of the Petrovka culture in Northern Kazakhstan. And radiocarbon dates of these layers corresponded to the early phase of Sintashta culture. This allowed us to conclude that the Alakul and Petrovka cultures had been formed simultaneously (but with some delay) with the Sintashta culture outside the Sintashta area in the steppe Transurals: Alakul culture to the north and northeast in the forest-steppe, and Petrovka to the east in the steppe. Moreover, the main component in their formation was Sintashta, but in both of these cultures there are numerous inclusions of East European Poltavka features (Fig. 18), poorly represented in Sintashta. The paradox is that in the Alakul ceramics of Mochishche, located too close to the Sintashta area, these Eastern European features are also not expressed. They are present to the east, in the Tobol area (Grigoriev, 2016; Grigoriev et al., 2018, pp. 156-158). It seems that the Sintashta people did not include Eastern European groups. Moving through Eastern Europe, they forced out some of these people further east. But soon after the formation of Sintashta culture in the steppe Transurals, they begin to actively interact with them, and this leads to the formation of Petrovka and early Alakul cultures. In this case, the proposal of N.B. Vinogradov to consider Petrovka culture as early Alakul has no ground. These were simultaneously existing cultures. It is assumed that at the end of the Sintashta culture existence, the Petrovka people from Kazakhstan moved to its territory, and then Alakul stereotypes spread into this kindred cultural environment from the forest-steppe, which led to the widespread distribution of the Alakul culture. But Petrovka sites appeared only in the eastern part of the Sintashta 


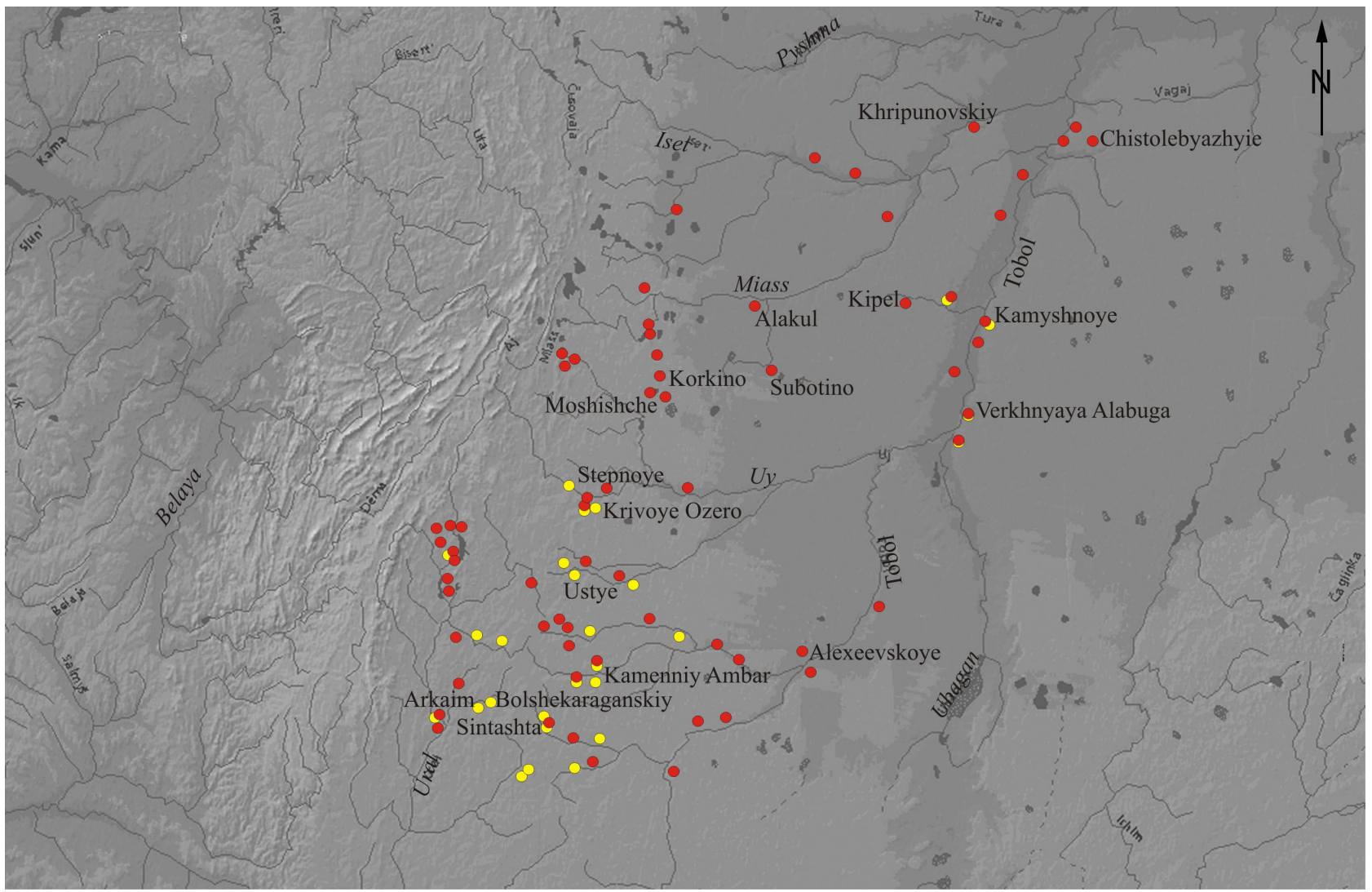

Figure 17: Map of the distribution of Sintashta (yellow circles) and Alakul (red circles) sites in the Transurals. The border between the steppe and forest-steppe is along the Uy River (after Grigoriev, 2008).

area, on the Tobol tributaries. In the west, on the tributaries of the Ural River, the Sintashta culture transformed into the Early Srubnaya culture (Fig. 19) (Grigoriev, 2008).

Therefore, I think this is a somewhat simplified model. The real situation was much more complicated, and this was characteristic of cultural genesis in the Andronovo area in general. After the formation of the Sintashta, Petrovka and early Alakul cultures, a colossal network of interaction formed, and the relations between its components in particular areas were very different. Sintashta settlements in the eastern part of the area were initially included in interaction with Petrovka groups in the east.

There is another paradox. The Petrovka complex of the settlement of Mochishche is closer to the Petrovka ceramics of the settlement of Ustye in the eastern part of the Sintashta area than to the Petrovka ceramics in the forest-steppe Tobol area and Northern Kazakhstan (Grigoriev et al., 2018, p. 110). Therefore, we may assume that in this area, the transformation of Sintashta ceramics into Petrovka was caused by this interaction earlier than in the western part of the area, and we may synchronize the beginning of the Early Alakul tradition north of Sintashta culture with this period. But without microchronology, we can only make unverified assumptions. Unfortunately, it will be very difficult to understand the specific mechanisms of this interaction, if it is not about speculation, but about specific research procedures. It is likely that the next years this problem will be solved on the materials of the Sintashta sites of the eastern area, on which later the Petrovka fortified settlements appeared, such as Ustye or Kamenniy Ambar (Vinogradov, 2013; Koryakova et al., 2011).

Paleogenetic studies provide some basis for understanding (Mathieson et al. 2015, p. 2, Extended Data, Fig. 2). In the Sintashta population, about half of the contribution was made by the Yamnaya descendants, and the rest by the descendants of the Anatolian farmers (Fig. 20). But already in the Andronovo population, the proportion of the Anatolian component decreases, and the proportion of the Yamnaya-Poltavka component increases. In this sampling, "Andronovo people" belong to Alakul complexes. This corresponds to the fact that, primarily, Eastern European 


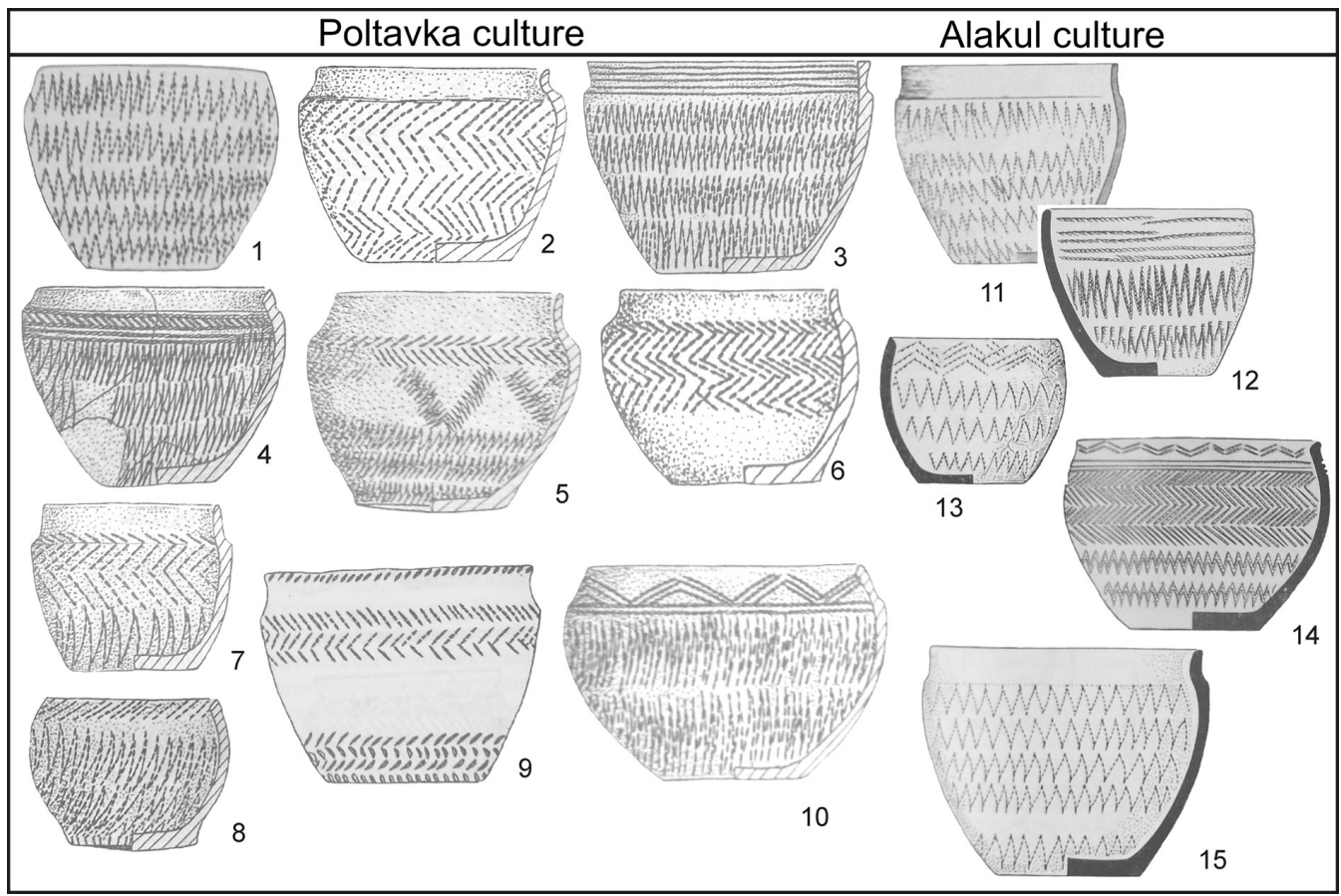

Figure 18: Comparison of Poltavka (1-10) and Alakul (11-15) ceramics: 1 - Shirochenka; 2 - Gvardeitsy II; 3 - Averyanovka I; 4 - Verkhnee Pogromnoe I; 5 - Chetyre Brata; 6 - Rovnoe 3; 7 - Chikovsky; 8 - Chelyuskinets; 9 - Maksyutovo; 10 - Khimkombinat; 11-15 - Verkhnyaya Alabuga (after Kiyashko, 2002; Mochalov, 2008; Potemkina, 1985).

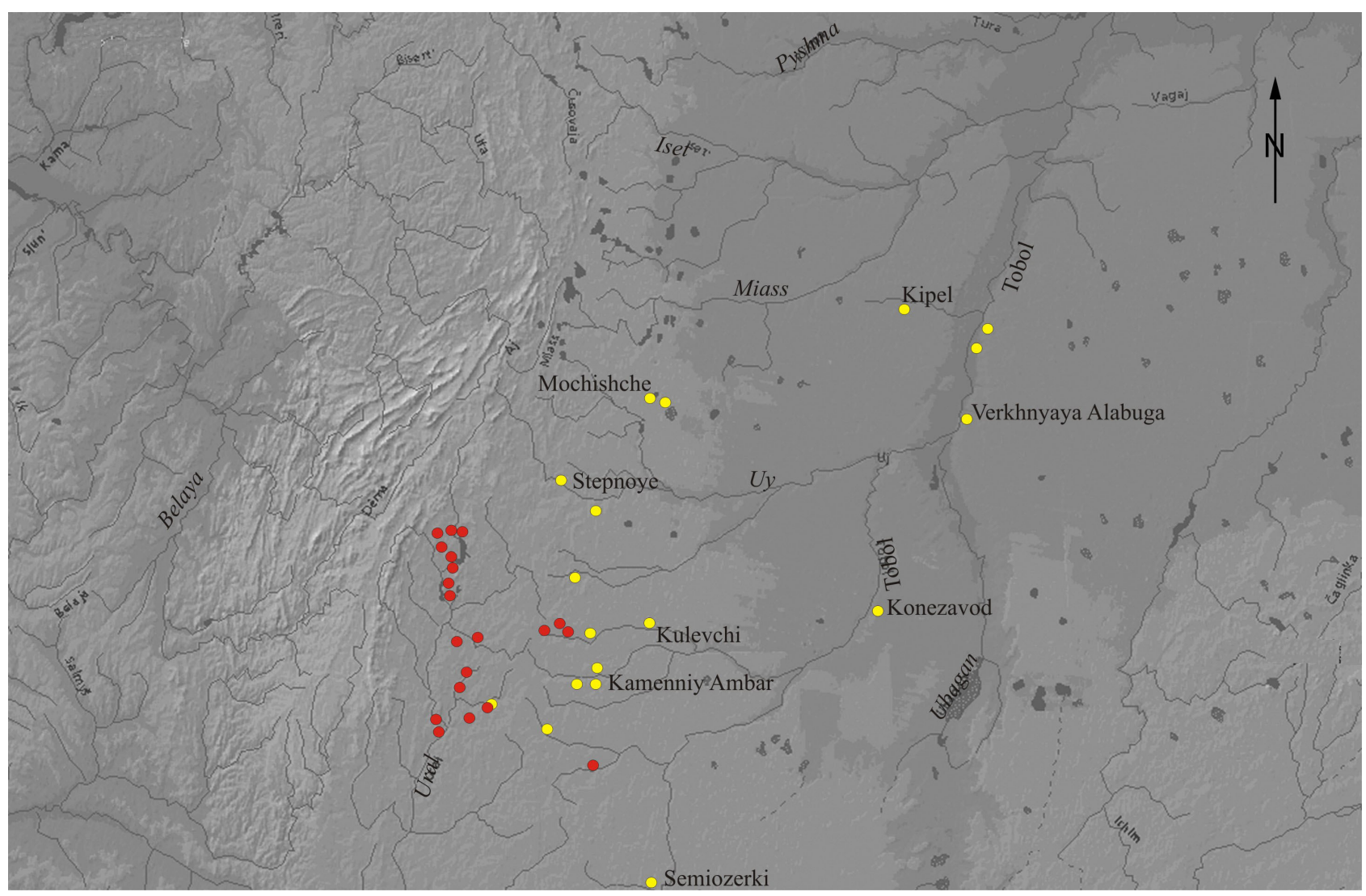

Figure 19: Distribution of Petrovka (yellow circles) and Early Srubnaya and Srubnaya-Alakul (red circles) sites in the Southern Transurals. The border between the steppe and forest-steppe is along the Uy River (after Grigoriev, 2008). 


\section{Armenian}

Eastern hunters and gatherers

Western hunters and gatherers

Anatolian Neolithic

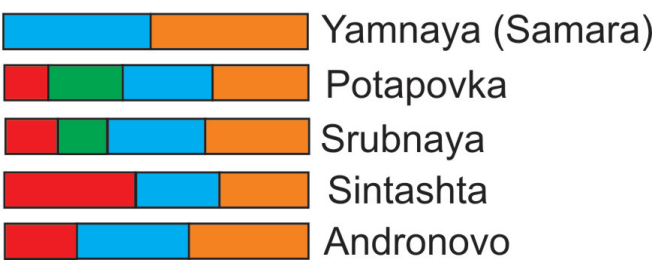

Figure 20: Genetic composition of the Early Bronze Age and Middle Bronze Age populations of Eurasia (after Mathieson et al., 2015, Extended Data, Fig. 2).

groups took part in the formation of the Petrovka and early Alakul cultures, with the undoubted cultural influence and demographic contribution of Sintashta. And the subsequent cultural genesis of the Alakul culture was associated precisely with them, and not with the inhabitants of the fortified Sintashta settlements in the core area of the culture in the steppe Transurals.

However, this also means that if for the Sintashta period we can discuss network interaction, at the end of the Sintashta's existence, the people from the forest-steppe and from Northern Kazakhstan moved to the steppe. And this movement must have had some reason. The most obvious is the coming of Fyodorovka people from the east. In the Transurals, the main part of Fyodorovka sites is located in the forest-steppe, where before that the early Alakul sites were situated. Points on the map in the steppe reflect single finds (Fig. 21). As mentioned above, these Fyodorovka sites are represented by cemeteries or an admixture of ceramics in the Alakul and Cherkaskul settlements.

This problem is closely related to the problems of the Cherkaskul culture. As we have seen, this culture was initially considered as synchronous to Fyodorovka and this opinion was preserved in further studies, as was the division of this culture into two stages (the third Beryozovoye stage of the Salnikov's scheme was abandoned), which culminated in the identification of two genetically related sequential cultures - Cherkaskul and Mezhovka, moreover, the origins of the Cherkaskul culture were seen in the Koptyaki type, which was formed on the basis of the Eneolithic Ayat culture of the forest Urals (Kosarev, 1981). Subsequently, this scheme was preserved, but it was suggested that the Koptyaki type, Cherkaskul and Fyodorovka cultures were formed on the basis of some "undivided type" combining Cherkaskul and Fyodorovka features whose origins remained undescribed (Fig. 22) (Obydennov \& Shorin, 1995, pp. 29, 45).

In the Koptyaki type, researchers always noted Alakul features (Khlobystin, 1976). Recent studies of the Shaitanka burial ground have revealed bronze objects of the Seima-Turbino type with Koptyaki ceramics. Analysis of this ceramics shows that it was formed on the basis of local Early Bronze Age complexes and Alakul ceramics, and this type was formed in Sintashta period (Korochkova, Stefanov, \& Spiridonov, 2020, pp. 109, 113, 116, 120). This corresponds to the hypothesis of the origin of early Alakul culture in this period in the forest-steppe zone of the Urals. Moreover, a combination of the Seima-Turbino, Alakul, Petrovka and Sintashta components was found in the Stepnoe VII cemetery at the border of the steppe and forest-steppe zones. According to the excavators, one can trace the evolution of these complexes (Kupriyanova, 2015, pp. 147, 148), but our analysis of this material shows their simultaneity (Grigoriev et al., 2018, p. 141). And all this explains the presence in the subsequent Cherkaskul culture of metalworking traditions coming back to the Seima-Turbino tradition (Grigoriev, 2002, p. 252). But we will not discuss here the most interesting problems of the Seima-Turbino bronzes, since they are not directly related to the Andronovo problem.

There is one important fact here: in the Urals there are settlements only with Mezhovka ceramics, but Cherkaskul ceramics in the settlements are always accompanied by Mezhovka ceramics. In addition, Mezhovka ware is typologically quite close to the settlement Fyodorovka ware in the eastern areas. There are ceramic forms that are intermediate between Fyodorovka and Cherkaskul. As a result, it was concluded that the Cherkaskul and Mezhovka ceramic types coexisted within the framework of the Cherkaskul culture. Gradually, the Cherkaskul type transformed and disappeared, and the Mezhovka type existed further within the Mezhovka culture. At the same time, the Cherkaskul type formed from the so-called Fyodorovka ware with rich combed decoration, and the Mezhovka type did from the settlement Fyodorovka ceramics (Fig. 16) (Matveev, 1998, p. 292, 2007, pp. 19, 23, 25, 30; Grigoriev, 1999, p. 248, 2000 , pp. 367, 368, 385). The transition from Cherkaskul to Mezhovka culture was very gradual: the number of wares of the Cherkaskul type was gradually reduced, the ceramic complex was transformed, and only the Mezhovka type remained in the culture (Grigoriev et al., 2018, p. 201). This conclusion seemed rather radical to us, but indeed, it is a replay of the V.S. Stokolos's scheme, which was not accepted by the scientific community. 


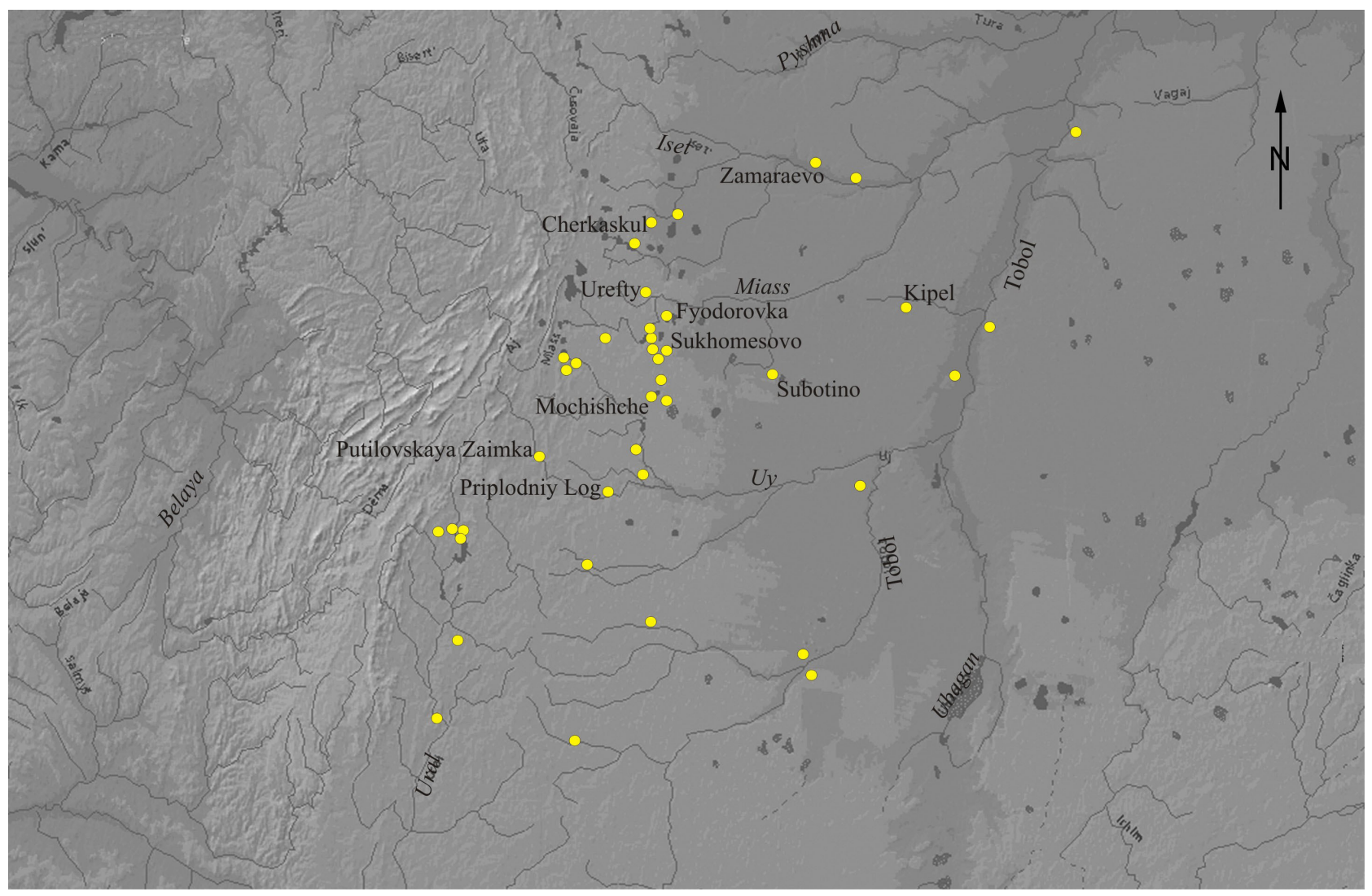

Figure 21: Map of the distribution of Fyodorovka sites in the Transurals. The border between the steppe and forest-steppe is along the Uy River and along the Ural Mountains (after Grigoriev, 2008).

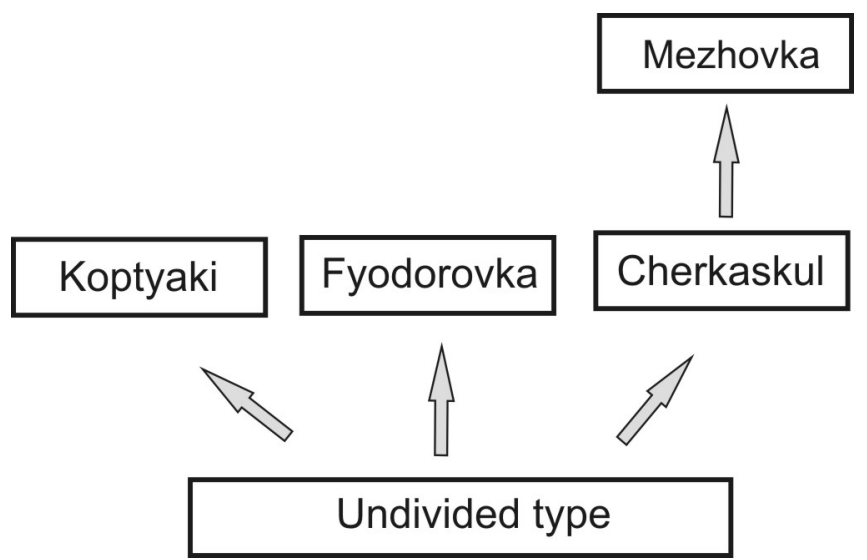

Figure 22: Scheme of Cherkaskul cultural genesis of M.F. Obydenov and A.F. Shorin (1995).

Judging by the materials of Mochishche, Fyodorovka ceramics in the forest Transurals appeared at the very end of the early Alakul village, but then it was present as an admixture in the Cherkaskul layers. And this is a common situation for Fyodorovka ceramics, which is usually an admixture of $5-15 \%$ in settlements of other cultures. Therefore, the question of the Fyodorovka subculture remains open. But this is also connected with the need to understand a nature of the Cherkaskul culture. Usually, after the works of M.F. Kosarev (1981), many cultures of the forest zone, located to the north of the Andronovo area, are customary named "Andronoid". These cultures include Cherkaskul, Pakhomovo, Suzgun, Elovskaya and others. As a matter of fact, they reflect the process of distribution of some Andronovo stereotypes in this 


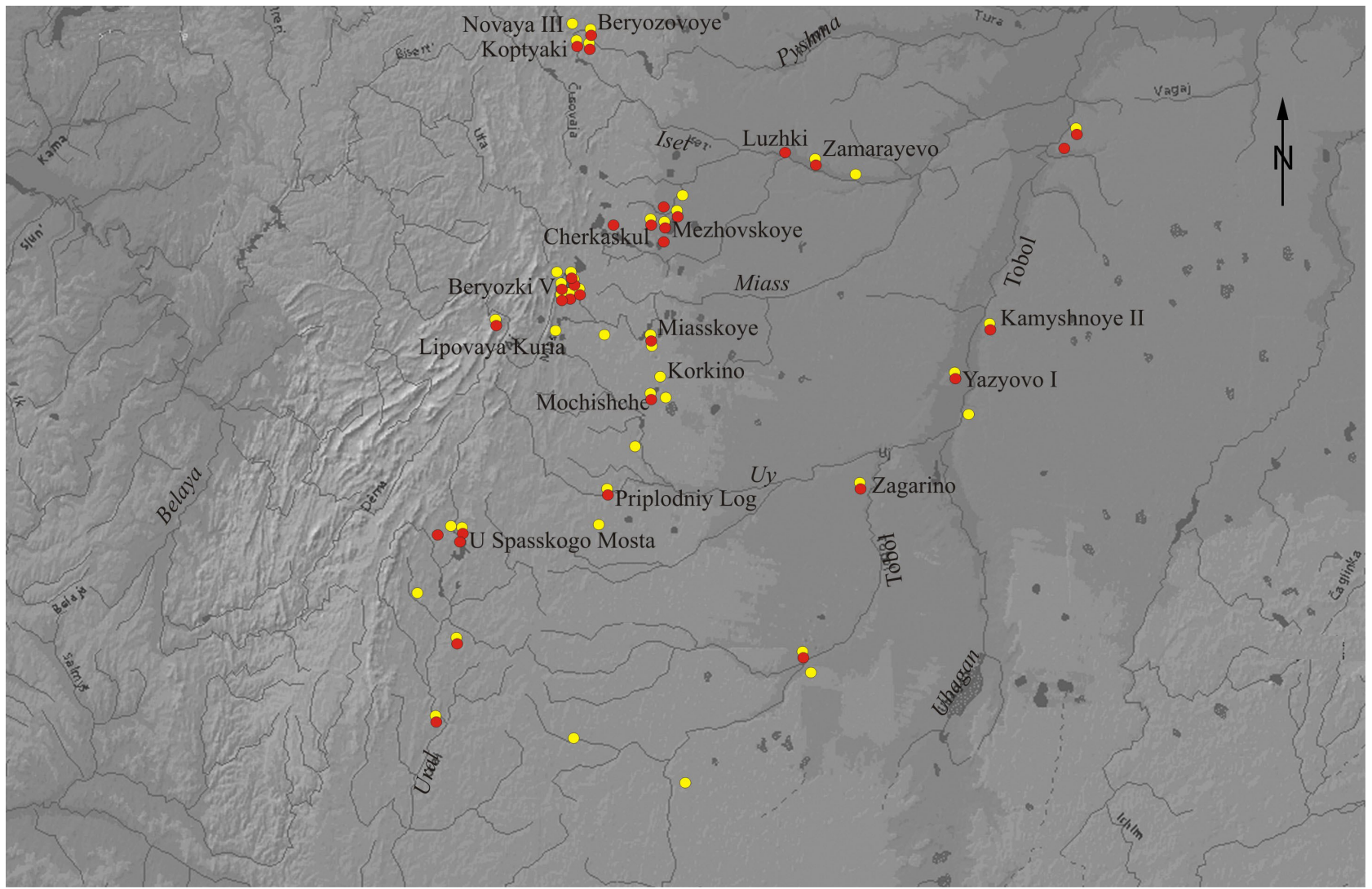

Figure 23: Map of the distribution of Cherkaskul (yellow circles) and Mezhovka (red circles) sites in the Southern Transurals. The border between the steppe and forest-steppe is along the Uy River and along the Ural Mountains (after Grigoriev, 2008).

zone. The degree of similarity between Cherkaskul ceramics and Fyodorovka ceramics is such that it can be considered as a variant of Fyodorovka ceramics. It is very difficult to distinguish the Mezhovka ceramics from the settlement Fyodorovka ceramics. However, despite the presence of the cremation ritual in the Cherkaskul culture, it was combined with inhumation. Fyodorovka cultural influence in the formation of the Cherkaskul culture was the principal, but all researchers agree that it should nevertheless be regarded as a separate culture.

This movement of Fyodorovka groups from the east led to two important consequences. First, a part of the early Alakul groups was forced out to the south, and Alakul stereotypes spread in the steppe zone. ${ }^{4}$ Assimilation of the related Petrovka culture took place. Secondly, in many areas the Alakul-Fyodorovka interaction is formed, and some Fyodorovka features appear in Alakul ceramics. This makes it possible to talk about the emergence of the Alakul culture of the high stage and the formation of the Andronovo cultural-historical commonality. For most regions, the forms of this interaction are a serious question, since almost everywhere Fyodorovka materials are present as an admixture. Unconditional Fyodorovka territories are Southern Siberia, possibly Eastern Kazakhstan, and partly, at some stage, the northern forest-steppe in the Tobol region, where Fyodorovka settlements are known. In some areas, Fyodorovka presence is more obvious in settlements, for example, in Central Kazakhstan, in others less. And the forms of this interaction, which formed the Andronovo system, remain unclear. There are even no primary hypotheses that would allow us to define a rigorous research procedure to study this situation.

It is likely that not all Alakul people of the forest-steppe Transurals migrated south to the steppe. A large number of Cherkaskul sites in the forest-steppe and in the south of the forest zone of the Transurals, against the background of a limited number of Fyodorovka sites, suggest that it was the former Alakul population that was the demographic base for

4 Among researchers who believe that Alakul and Fyodorovka were not genetically related, there is another point of view. Alakul origin is expected to be later than described here. This origin was associated with Fyodorovka migration from the east, the influence of Fyodorovka culture on the Sintashta-Petrovka population, and this led to the formation of the Alakul culture (Bobrov, 2014, p. 276). 
the Cherkaskul culture, but only demographic, since the Fyodorovka influence was decisive in cultural terms. Perhaps, the later penetration of the Cherkaskul culture to the south and southeast, to the steppe, to the new "Alakul" territories, was partly also connected with this. A series of Cherkaskul sites was identified for these years in the Transural steppe (Stefanov, 1996; Obydennov \& Shorin, 1995, pp. 36-37; Evdokimov, 1983, p. 44; Potemkina, 1975, p. 38; Grigoriev, 2000, p. 359; Logvin \& Shevnina, 2013; Malyutina, Zdanovich, \& Petrova, 2006) and in Kazakhstan (to the latitude of Astana) (Zdanovich S., 1984, pp. 74-76). They are not completely identical to the sites of the forest-steppe and forest zones, but, nevertheless, they are Cherkaskul sites.

Thus, the formation and functioning of the system, which is commonly named the Andronovo cultural-historical commonality, was a much more complex process.

\section{Problems of Sargari Culture}

A separate problem is the origins of steppe complexes with cordoned ware of the Final Bronze Age. E.N. Chernykh (1983) suggested for Eurasia a Commonality of Cordoned Ware Cultures, which included several cultures from the Danube to Altai and the south of Central Asia. The basis for identification of this commonality was the presence of the applied cordon in the upper part of the vessels and many common forms of metal objects. These cultures were divided into two territorial zones. The western zone includes the cultures of Noua, Coslogeni and Pšeničevo-Babadag, and the eastern one - Ivanovskoe (Srubno-Khvalinsk in earlier terminology) in the Volga region, Sargari from the Urals to Eastern Kazakhstan, Begazi-Dandibay in Central Kazakhstan, Trushnikovo type in Eastern Kazakhstan, Amirabad culture and type Yaz I in the south of Central Asia. The contact cultures between these zones included the Sabatinovka culture and the Belozerka culture that replaced the former in Ukraine. At first glance, the isolation of this commonality was artificial. The use of this term even for Andronovo cultures raises questions. It is obvious that the cultures on the Danube have little in common in terms of origins and interaction with the eastern cultures. Both the Sabatinovka and Belozerka cultures of Ukraine were connected, first of all, with them, and not with the Ivanovskoe culture of the Volga region, although in this case intensive contacts cannot be denied, which determined their position in this commonality. The cultures of the south of Central Asia have a later indirect connection with the cordoned cultures of the steppe, which is not related to the topic discussed here. But the Ivanovskoe and Sargari cultures and the Trushnikovo type are very culturally similar and were formed as part of a single process. Two things are important to our topic. The isolation of this commonality by Chernykh brought the Sargari culture out of the Andronovo commonality. Sometimes one can find a description of the Final Bronze Age metal as Andronovo one (Ivanov, 2014, pp. 91, 99). But this is nothing more than a tribute to tradition; among experts, such an opportunity is no longer being discussed. But in adjacent territories this is the case. For example, in Xinjiang, the presence of sites with the features of steppe cordoned ware cultures is considered as the influence of the late Andronovo culture, although everyone correctly understands their chronological position (e.g., Mei \& Shell, 1999, pp. 572, 573, 578; Mei, 2000, pp. 14, 25, 27, 28, 36, 60). There is one more problem: in different territories, these related cultures were preceded by different complexes: in the Volga region - Srubnaya, in the Urals and Kazakhstan - late Alakul, in Eastern Kazakhstan - late Fyodorovka. Consequently, their unity was provided not by these previous cultures, but by some single process. And it is important that for the Transurals and Kazakhstan it is a steppe culture; in the forest-steppe, finds of these ceramics are very rare (Fig. 24).

In Central Kazakhstan, Sargari materials existed simultaneously with Begazi-Dandibay. At the same time, the researchers see the situation that we discussed for Fyodorovka and Alakul cultures. There are rich Begazi-Dandibay cemeteries here, but in the settlements, Begazi-Dandibay ware is present as a small admixture in the Sargari layers. This is understood as the appearance of some elite with southern and eastern relations (Beisenov, Varfolomeev, \& Kasenalin, 2014). But the Sargari ware had no origins in local ceramic traditions. Its weak ornamentation and forms also indicate southern influences (Loman, 2013, p. 257).

Thus, already in the Final Bronze Age, we have no reason to discuss the Andronovo culture. The same happened in Southern Siberia, where the Andronovo culture did not exist by that time, and it was replaced by the Karasuk culture, which is related to Begazi-Dandibay.

Based on the said above, under Andronovo cultures we can only understand cultures that formed after the movement of bearers of the Fyodorovka ceramic tradition to Kazakhstan and the Transurals. Sintashta, Petrovka and 


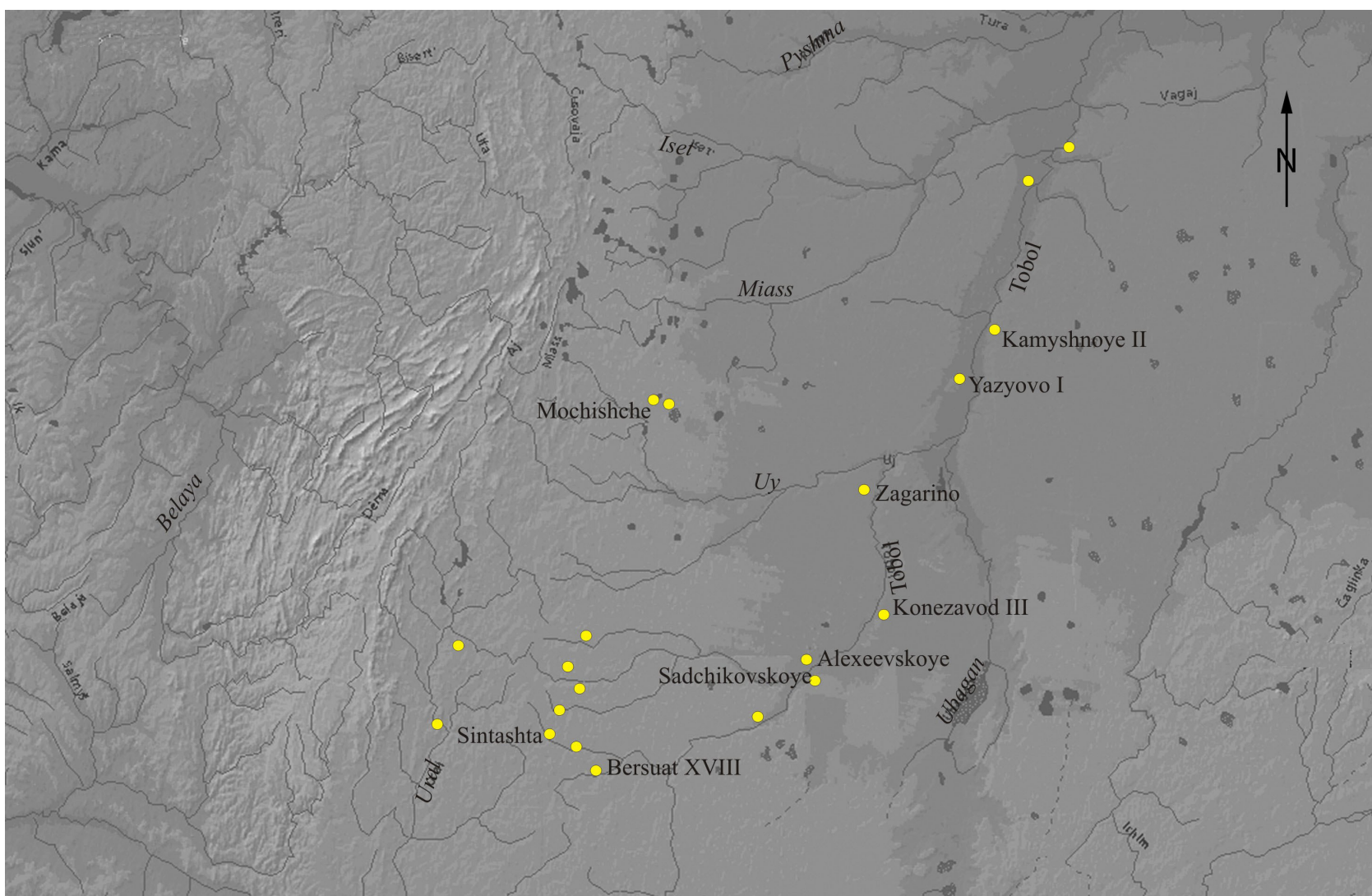

Figure 24: Map of the distribution of Sargari sites in the Southern Transurals. The border between the steppe and forest-steppe is along the Uy River (after Grigoriev, 2008).

even early Alakul are cultures of the pre-Andronovo period. Andronovo includes only the Alakul culture of the high and late stages, Fyodorovka, as well as a series of cultures that were formed on the northern periphery of the Andronovo area (Cherkaskul, Pakhomovo, etc.). But the latter may be understood rather as Andronoid cultures.

\section{Problems of Chronology}

As we saw from the above description of the processes, they were very dynamic, multidirectional, a combination of various migrations and network interactions. At the same time, old cultural stereotypes could persist on some territory, and new ones could arise earlier than anticipated in the previous period, as was the case with the early Alakul and Petrovka cultures. This is a very revealing example. If I were asked to express their chronological relationship in three words, I would say: "Sintashta - Petrovka - Alakul", because globally in different territories, and from the point of view of cultural genesis, the perception of certain components of the predecessors, this is exactly so. But the reality that we discussed above is much more complicated. Under these conditions, we cannot fully rely on local stratigraphy and typology. As we have seen, these crazy changes of opposite points of view were caused by the fact that local situations were regarded as having a general meaning that could be applied to all Andronovo areas. From the point of view of a specific material and local situation, most of these points of view were completely justified. Moreover, I should note that the description of these processes and individual concepts given above is extremely simplified by me, I touched on the problems of the Transurals only a little more, although even the Transural situation is described almost primitively. In other areas, these processes are just as complicated and confusing. But in order to correctly understand them, a very detailed chronology of the complexes is needed, and this is a big problem today. 
In addition to typological and stratigraphic analysis, in practice, the only method for this is radiocarbon. However, it has very wide confidence intervals. In the case of using dates with a rather low probability of $68.2 \%$, we get intervals of 200-300 years. And in a situation of complex dynamic systems, we are not able to study them. With a higher probability of $95.4 \%$, we are completely deprived of this opportunity, since the intervals become too wide. Therefore, we are able, after a large series of analyzes, to compare the intervals of two different cultures using statistical operations. But here, some difficulties await us. The accumulation of dates for this huge territory is quite slow, and usually used dates are made in different laboratories, by different methods and in different years. These dates are very often not comparable with each other. An example is the work of P. Ashmore in Scotland, which showed that when using 129 dates with an error of less than 50 years, their peak occurred in $4000 \mathrm{BC}$, and when using 45 dates with an error of less than 10 years, this peak is around $3800 \mathrm{BC}$ (Ashmore, 2004, p. 126). Modern AMS dates give not only narrower, but also younger intervals. Therefore, we can only understand the situation when we get a large series of AMS dates for different Andronovo areas. The first such attempt was made by Hanks, Epimakhov, \& Renfrew (2007). They only used 40 dates, so some of the intervals were incorrect. But in general, it was concluded that in the Transurals, Sintashta had an earlier chronological position relative to Petrovka, and the dates of Petrovka and Alakul were comparable. The relatively early Fyodorovka interval was also identified. Accordingly, doubts were raised about the genetic line Petrovka - Alakul Fyodorovka.

A more complete generalization of the Bronze Age dates of the Urals and Siberia appeared later (Molodin, Epimakhov, \& Marchenko, 2014). But the total results given in this work are not quite comparable, since for some cultures all available dates are used, and for some, only AMS dates, and all others are considered unreliable. Therefore, if the entire sampling of Sintashta dates falls within the range of 2200-1650 BC (with the presence of clearly unreliable earlier dates), which, in general, corresponds to the Abashevo dates (Chernykh, 2007, p. 86), when using mainly AMS dates, we get a more correct interval of 2010-1770 BC (Molodin et al., 2014, p. 140). A small series of dates of Petrovka culture (18 dates, of which 5 are AMS dates) fit into an incredibly wide interval 2500-1200 BC. Therefore, its position was determined by AMS dates within the range 1880-1750 BC. Thus, these dates correspond to the Sintashta interval, but the lower boundary of the interval is younger. But these are the dates of two sites, Ustye and Kulevchi (Molodin et al., 2014, p. 142), which are located on the territory of Sintashta culture, where Petrovka stereotypes penetrated later. Recently, new AMS dates have been received for Petrovka sites located on the northern periphery of the Sintashta area (Stepnoe VII, Troitsk-7), which also fit into the interval of the $19^{\text {th }}-18^{\text {th }}$ centuries BC (Krause, Epimakhov, Kupriyanova, Novikov, \& Stolyarchik, 2019, pp. 61, 62). All this indicates the synchronization of Petrovka culture with most of the Sintashta interval, although Petrovka began somewhat later. However, we are talking about the dates from the periphery of the Sintashta area. We do not have comparable series from Northern Kazakhstan, where Petrovka stereotypes should have appeared earlier.

An even more difficult situation is with the dating of Alakul culture. In general, its dates fit into the interval 2300$1450 \mathrm{BC}$, and the early part of this interval is considered unreliable (Molodin et al., 2014, p. 143). The fact is that these dates are formed by the analysis of samples of the Chistolebyazhyie and Khripunovskiy cemeteries, without using accelerator technology. And most of these dates fall into the $3^{\text {rd }}$ millennium BC (Matveev, 1998, pp. 359-373; Matveev, Volkov, \& Kostomarova, 2007). The dispersion of these dates, as well as the Alakul dates of the Subotino cemetery in the forest-steppe Tobol area, is very large $\left(23^{\text {rd }}-16^{\text {th }}\right.$ centuries BC). But in the same interval, the date from the Alakul well of the settlement of Korkino near Chelyabinsk falls (2120-1940 BC) (Epimakhov, 2016, pp. 63, 64). The date of the Nizhneingalskoe-3 settlement in the Tyumen region also corresponds to the $22^{\text {nd }}-21^{\text {st }}$ centuries $B C$, as well as a series of dates from the settlement of Mochishche (Ryabogina, Matveeva, \& Orlova, 2001, p. 206; Grigoriev et al., 2018, p. 165). This was one of the reasons for the partial synchronization of Alakul culture with Sintashta. This position met a completely fair objection: the Alakul dates, which are older than the Sintashta interval, do not merit confidence, since the Alakul culture formed on the Sintashta basis, and it could not had been formed earlier. In addition, these dates were not made using accelerator technology (Krause et al., 2019, p. 61). All this is absolutely true, but only comparable things should be compared, and we compared this early Alakul interval with exactly the same Sintashta dates, whose range begins from $2200 \mathrm{BC}$ (Chernykh, 2007, p. 86). And we never wrote about an earlier chronological position of Alakul.

If we use the latest AMS dates, we get an even more complicated picture. Two Alakul dates of the cemetery of Stepnoe VII (19 ${ }^{\text {th }}-18^{\text {th }}$ centuries BC) correspond to the Petrovka dates of this monument (Krause et al., 2019, p. 61). But this also corresponds to the second half of the Sintashta interval. In principle, the materials of this cemetery located in the contact zone allow us to talk about the interaction and coexistence of these cultural complexes. 
Very high-quality dates of the Alakul burials of the Lisakovsk cemetery in the steppes of the Tobol area also correspond to the $19^{\text {th }}-18^{\text {th }}$ centuries BC (Panyushkina et al., 2008; Usmanova \& Panyushkina, 2011, p. 378; Molodin et al., 2014, p. 143). The dates of Alakul burials of the Kulevchi VI cemetery fall into the same interval (Epimakhov, 2016, p. 64). The problem is that the first of these cemeteries is located in the area of Petrovka culture, and the second in the east of the Sintashta area. And these dates are fully compatible with the Petrovka interval and a significant part of Sintashta one. In Northern Kazakhstan, three dates of the Alakul burials of the Baikara cemetery clearly fit in 1740-1520 BC (Görsdorf, 2003). That is, in this "Petrovka" territory, Alakul culture appeared later. And this is close to the date of the Alakul-Fyodorovka burial in the Lisakovsk cemetery (1719 \pm 50 BC) (Usmanova \& Panyushkina, 2011, p. 378). This corresponds to what we wrote above about the distribution of Alakul stereotypes from the forest-steppe to the south as a result of pressure of the Fyodorovka tribes from the east. It can be assumed that according to the AMS dates this occurred around the middle of the $18^{\text {th }}$ century $\mathrm{BC}$, and this is a bit later, but generally close to the final dates of Sintashta. But it is difficult to explain the earlier Alakul dates in this way. In view of the small series of these dates, we can assume both erroneous dating and rather complicated interaction networks when people with another ceramic culture appeared in border areas. In the latter case, however, we would have individual Alakul materials in various Sintashta complexes inside the core area, which is not so. Therefore, it is more likely that even the intervals determined by the AMS dates are too wide, and the intervals of different periods partially overlap one another. The real interval of Sintashta culture is somewhat shorter, and in the $18^{\text {th }}$ century BC (in radiocarbon chronology) this movement of Alakul stereotypes to the south began. But this question is very far from being resolved.

Nevertheless, from all that has been said above, we can conclude about identical intervals of Petrovka and early Alakul dates, and about the proximity of this interval to a significant part of the Sintashta interval.

A fundamentally important relation of Alakul and Fyodorovka complexes is also poorly studied by the radiocarbon method. In the Transurals, only five Fyodorovka dates give a wide interval of 1980-1510 BC, which does not allow us to talk about the sequence of Alakul and Fyodorovka cultures. In the Baraba forest-steppe of Southern Siberia, Fyodorovka dates show the interval 1800-1500 BC, in the Minusinsk Basin on the Yenisei - 1900-1500 BC, and in the Upper Ob and Altai - 2000-1700 BC (Molodin et al., 2014, pp. 144, 145). The Fyodorovka dates in the north of the foreststeppe Tobol region are close to the dates in the Southern Transurals and lie in the interval of the $20^{\text {th }}-16^{\text {th }}$ centuries BC (Zakh, Ryabogina, Ilyushina, Ivanov, \& Murzina, 2013, p. 18; Ilyushina, 2015, p. 46). In Xinjiang, at the settlement of Adunqiaolu, dates from the $19^{\text {th }}$ century BC were obtained, from which it was concluded that the traditional ideas about the spread of the Fyodorovka culture from west to east are not correct (Jia, Betts, Cong, Xiaobing, \& Dupuy, 2017). In fact, there are also very early dates in the west, and in Russian archeology there have always been ideas about the spread of this culture from the east. Unfortunately, radiocarbon analysis is not able to solve this problem yet.

These are very unreliable series from a mixture of dates of different types, these intervals are unreliable and possibly extended, but they are in good agreement with each other, and we can draw two reliable conclusions from this: 1) Fyodorovka culture, in general, is synchronous with Alakul, and we can forget about the genetic continuity of the Alakul and Fyodorovka cultures; 2) on this basis it is very difficult to show the earlier position of Fyodorovka culture in Eastern Kazakhstan; it is possible that this Fyodorovka migration to the west began shortly after the culture formation.

Dating of the Cherkaskul and Mezhovka sites is built on only 13 old dates, and their age is determined within 1610-1260 BC. This is a very unreliable series. But it shows a later interval relative to Fyodorovka (Molodin et al., 2014, p. 142). But the problem is that this is not an interval of the Cherkaskul culture, it is an interval of the Cherkaskul and Mezhovka cultures. Accordingly, the Cherkaskul culture formed somewhat later than the Fyodorovka culture and then coexisted with it, as well as with the Alakul culture of the high stage in the steppe. But it is later than the early Alakul sites of the Transural forest-steppe, where the Cherkaskul culture formed. Mezhovka culture existed partially during the period of the Cordoned Ware cultures of the steppe zone. The latter are very poorly provided with dates. In general, they are dated to the $14^{\text {th }}-9^{\text {th }}$ centuries BC (Molodin et al., 2014, p. 144). This is a very wide interval. S.Ya. Zdanovich (1984, p. 93) outlined the division of the Sargari culture into early and late stages, and for the latter, the interval $12^{\text {th }}-9^{\text {th }}$ centuries BC was obtained at the settlement of Mochishche (Grigoriev et al., 2018, p. 206).

There is also another problem connected with the latter interval. Despite the assertions that the cultures of the Bronze Age in the steppe were the basis for the origins of cultures of the Scytho-Sarmatian world (Kuz'mina, 2007, pp. 366-411), this is not confirmed by real material. We see a gap between the dates of the Sargari complexes and the Sarmatian ones. But we also do not have typological series that would allow us to show this connection. In Ukraine, there is no such gap, but the stereotypes of Scythian culture were clearly born not there, but were brought from Southern 
Siberia (Murzin, 1990, pp. 16-31). Therefore, the formation of the Scytho-Sarmatian culture in Southern Siberia is more likely. It was not even connected with the Sargari complexes of the Final Bronze Age, and moreover, it had no connection with the Andronovo World.

Thus, in general, the situation with radiocarbon dating of Eurasian cultures within the Andronovo area is still very unconvincing. But it allows us to see the most general processes. Obviously, the Petrovka and early Alakul dates coincide with the Sintashta dates, although their intervals begin somewhat later than the beginning of the Sintashta culture. Fyodorovka culture, in general, has the same date interval as Alakul. Therefore, the theory of their genetic continuity is not confirmed by these dates. Cherkaskul culture formed later than the beginning of Fyodorovka, but it partially coexisted with the Fyodorovka and Alakul cultures, which is well confirmed by all other materials. Around the beginning of the $14^{\text {th }}$ century BC the Andronovo system ceased to exist and was replaced by Cordoned Ware cultures in the steppe and Karasuk culture in southern Siberia.

\section{Social Aspects of Cultural Genesis in Eurasia}

The problem of cultural genesis in the Eurasian Bronze Age is complicated by the fact that earlier the movement of some culture was considered as a reflection of migration. This is often true. There were some kind of interaction networks, sometimes quite extensive. For the Andronovo period, these broad networks were caused, primarily, by the fact that tin alloys were used at that time, and the sources of tin were mainly in Altai, partly in Central Kazakhstan and Uzbekistan. This is characteristic of different Eurasian regions (Garner, 2013). And here the problem cannot be limited only to the problem of organizing these large-scale tin deliveries. This was accompanied by increased copper trade. Everywhere it was necessary to establish the production and exchange of some goods in order to be included in this global network (Grigoriev, 2017). This had already created second-order interaction networks.

However, it would be a mistake to limit all these interactions to metal trade. It was probably an important, but not the main factor. There is a specificity of the distribution of sites in the Eurasian steppe and forest-steppe, which takes place from the beginning of Sintashta culture to the end of the Bronze Age. In a very simplified form, this specificity can be formulated as follows: there was some territorial core of a culture where settlements and cemeteries are known, and there are areas where this culture is represented only by cemeteries and admixtures of ceramics in settlements of other cultures. Moreover, very often in these areas burials of this culture are more magnificent than burials of representatives of local culture. A similar situation was first recorded in Sintashta time: there is the core area in the steppes of the Southern Transurals, and there are areas where only burials are found (Potapovka monuments in the Volga region, Sintashta monuments in the west of the Southern Urals and the Tobol area). This situation was repeated in Andronovo period: there are areas where Fyodorovka culture is represented by settlements and burials (Southern Siberia, the northern forest-steppe of Western Siberia), and there are areas where we know only cemeteries (for example, the foreststeppe of the Southern Transurals). In the Final Bronze Age, we have an identical situation with the Begazi-Dandibay monuments of Central Kazakhstan. This stable paradox indicates the existence of some other systems of interaction, possibly the dominance or control of some territory. Probably, these systems were different in different periods and in different areas. Unfortunately, today we do not have reliable tools to study this problem, and we can only speculate on this topic.

In addition to similar relatively global processes, there were processes of a more local level associated with marriage and other forms of relationships. Therefore, the real process of cultural genesis was the sum of all these factors, with their different combinations in individual areas.

\section{Conclusion}

In this article, I have shown the dramatic history of the Andronovo studies, which survived several mutually exclusive schemes of cultural genesis. As mentioned above, the situation here is very simplified. Unfortunately, in modern Western literature very often randomly selected fragments of a particular scheme are used. Generally, it is quite normal when it is used to local processes. As we have seen, most of these schemes were based on completely objective research 


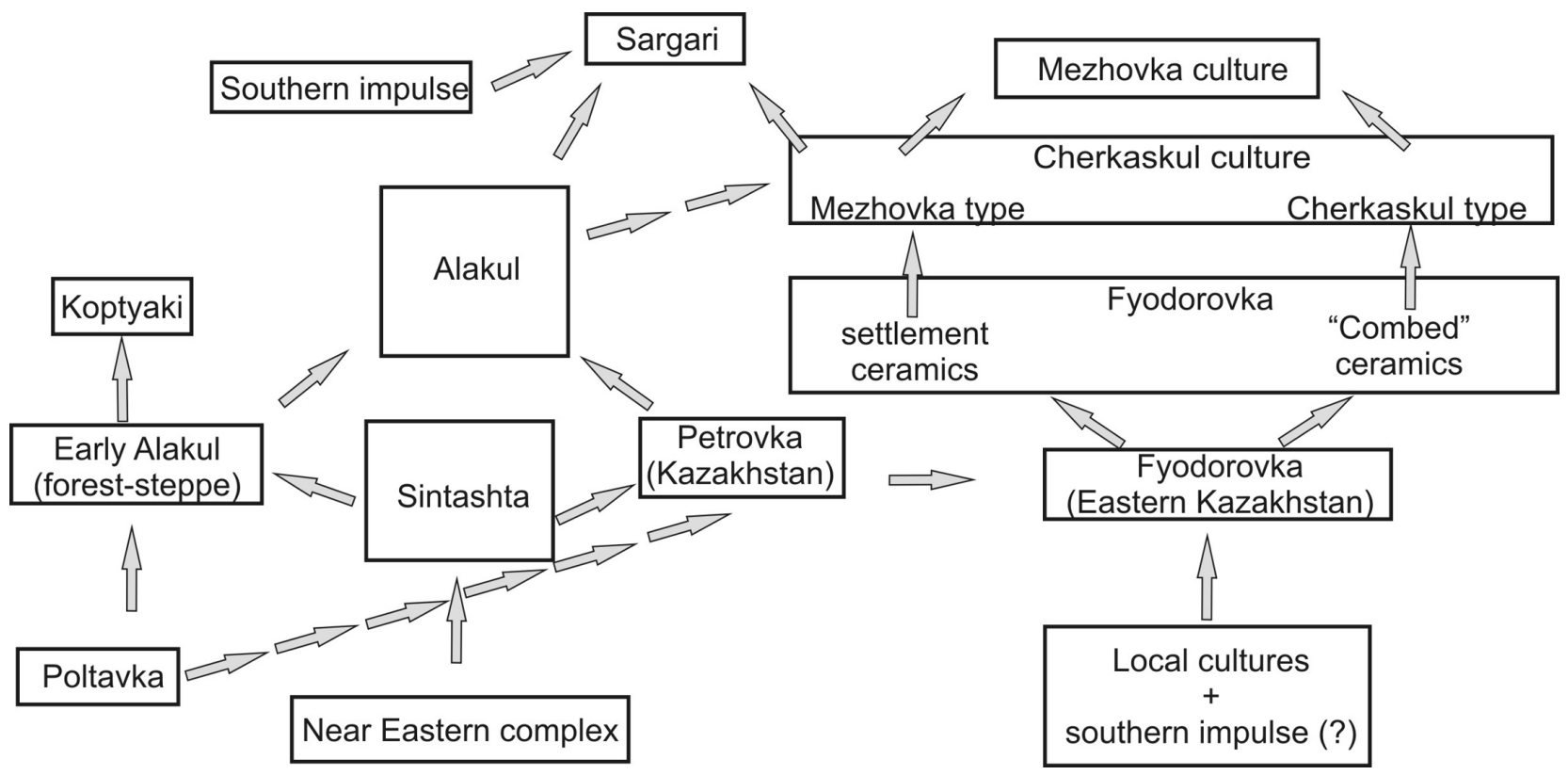

Figure 25: Scheme of cultural genesis in the Bronze Age in the Southern Transurals.

situations. However, when discussing global processes, the problems arise. It was these attempts to understand a local situation as having a universal significance for the huge region was the reason for the existence of the Andronovo problem. Moreover, even within individual territories, for example, the Southern Transurals, these processes were very different in individual areas.

Today it is obvious that the formation of the Bronze Age cultures of the area under discussion began with the penetration of the bearers of Sintashta culture into the Transurals. The subsequent spread of part of this population to the east, north, and northeast led to the formation of Petrovka and early Alakul cultures (Fig. 25). Therefore, the genesis of the Alakul culture is quite clear, and some clarifications are possible only in relation to the chronology of this process and its mechanisms. It is possible that, in a very weakened form, these impulses reached Upper Irtysh in Eastern Kazakhstan, where the Fyodorovka culture was forming. However, its formation was based on completely different processes, and this culture was not connected with the Sintashta-Petrovka-Alakul tradition. Now we are not even able to find approaches to solving this problem. On the one hand, in the settlement ceramics, we see some features that were inherent from the pre-Andronovo ceramic complexes of southern Siberia and Eastern Kazakhstan. We can find local origins for contracted inhumations on the side in stone boxes and cists in previous cultures of southern Siberia. We can find some features even in Sintashta pottery, but it is not certain that this limited similarity is not accidental. We see some analogs to metal in the Middle East. Therefore, in general, we may assume the Fyodorovka cultural genesis on the basis of three components: 1) a local component, 2) a component came from the west (Sintashta-Alakul area), 3) a component came from the south. Notably, all of this has been badly studied. In my opinion, there are three main questions, answering which we will find a solution of the problem: 1) where did Fyodorovka burial ware with polished surface ornamented with a magnificent decoration with combed stamp come from? 2) where did the ritual of cremation come from (previously absent in the Urals and Siberia)? 3) why, against the background of the identical burial ceramics, burials in the west are represented by cremation, and in the east by inhumation?

Finally, at the beginning of the Final Bronze Age, some southern impulses lead to the formation of the BegaziDandybay and Sargari cultures, forming a rather stable and very monotonous cultural system for many years. These cultures are already beyond the "Andronovo culture" or the "Andronovo cultural-historical commonality". Within the Urals and Kazakhstan these cultures were in no way associated with subsequent cultures of the Early Iron Age. In any case, today there are no facts in favor of this. In Southern Siberia, the Karasuk and Lugavskaya cultures have strong connections with the subsequent cultures of the Scytho-Siberian World. 
There is a very serious problem of terminology. The term "Andronovo culture" is absolutely inappropriate. But the term "Andronovo cultural-historical commonality" also gives nothing to understand the system that formed at this time. These terms reflect the presence of some similarities between Fyodorovka culture and the Alakul culture of its high stage. But this similarity is manifested only in some features of ceramic decoration, as well as in the existence of very rare contact types. The differences between these cultures are too great. Just in the early stages of research, due to the extremely limited knowledge, some similarities were striking. Therefore, before the appearance of works with a deep justification for this term, it is better to avoid its use. It is very clear that it is absolutely inappropriate when discussing not only the Sargari culture, but even the Petrovka and early Alakul cultures. It reflects only the interaction of the bearers of two cultures of different origins: Fyodorovka and Alakul culture at its high stage. But such interactions are not something unique in archeology, and we are not trying to name it as some kind of culturalhistorical commonality or a single culture. The existence of this terminology is the result of the research tradition described in this article. Unfortunately, currently we do not have an optimal solution to this terminological problem. Due to this interaction of two components, Alakul and Fyodorovka, Alakul has common Andronovo features, therefore the general term "Andronovo" is quite applicable to it. However, we may not use this term only as a designation of the Andronovo cultural-historical commonality, consisting of the Alakul and Fyodorovka cultures, since we may not apply the term "Fedorovka" to the sites in Southern Siberia and Eastern Kazakhstan, which have identical ceramics with the Fyodorovka sites of the Transurals: burials in the Urals are represented exclusively by cremation, and in Southern Siberia exclusively by inhumation. Therefore, at this stage, I do not see a way out of this terminological impasse; and I think that new attempts to change terminology and multiply entities should not be produced. This will only become possible when we clarify the mechanisms of formation of these cultures and the mechanisms of their interaction, which caused the emergence of some similar features.

Cultural genesis in the Eurasian steppe and forest-steppe was caused by a series of multidirectional migrations, as well as very complex processes of formation of interaction networks of various sizes and types. Studying them is a very difficult challenge for future researchers, but an aspect of academia that is quite possible.

Acknowledgments: I am very grateful to my teacher, G.B. Zdanovich, who introduced me to the Andronovo research, as well as anonymous reviewers who contributed to the improvement of this article.

Funding Information: Author states no funding involved.

Conflict of Interest: Author states no conflict of interest.

Data Availability Statement: Data sharing is not applicable to this article as no datasets were generated or analysed during the current study.

\section{References}

Anthony, D. W., \& Ringe, D. (2015). The Indo-European homeland from linguistic and archaeological perspectives. Annual Review of Linguistics, 1, 199-219.

Ashmore, P. J. (2004). Absolute chronology. In I. A. G. Shepherd \& G. J. Barclay (Eds.), Scotland in Ancient Europe (pp. 125-138). Edinburgh: Society of Antiquaries of Scotland.

Avanesova, N.A. (1991). Kul'tura pastusheskih plemen jepohi bronzy Aziatskoj chasti SSSR. [The culture of the pastoral tribes of the Bronze Age in the Asian part of the USSR]. Tashkent: FAN. [in Russian]

Beisenov, A. Z., Varfolomeev, V. V., \& Kasenalin, A. E. (2014). Pamjatniki begazy-dandybaevskoj kul'tury Central'nogo Kazahstana. [Monuments of the Begazi-Dandybay culture of Central Kazakhstan]. Almaty: Institut arheologii im. A.H. Margulana. [in Russian]

Bobrov, V. V., \& Mihailov, Ju. I. (1989). Pamjatniki andronovskoj kul'tury Ob'-Chulymskogo mezhdurech'ja [Monuments of the Andronovo culture of the Ob-Chulym interfluve]. Kemerovo: University press. [in Russian]

Bobrov, V. V. (1993). Andronovskaja kul'tura ili kul'turno-istoricheskaja obshhnost'? [Andronovo culture or cultural-historical commonality?], Ural historical journal, 1, 9-10. [in Russian]

Bobrov, V. V. (2014). Osobennosti andronovskogo pogrebal'nogo obrjada v vostochnyh rajonah areala kul'tury [Specifics of the Andronovo funeral rite in the eastern regions of the cultural area]. In V. I. Molodin, A. V. Epimakhov (Eds.), Arii stepej Evrazii: epoha bronzy $i$ 
rannego zheleza v stepjah Evrazii i na sopredel'nyh territorijah [Arias of the steppes of Eurasia: the Bronze and Early Iron Age in the steppes of Eurasia and in adjacent territories] (pp. 268-278). Barnaul: Altai University. [in Russian]

Botalov, S. G., Grigoriev, S. A., \& Zdanovich, G. B. (1996). Pogrebal'nye kompleksy epohi bronzy Bol'shekaraganskogo mogil'nika (publikaciya rezul'tatov arheologicheskih raskopok 1988 goda) [Burial complexes of the Bronze Age of the Bolshekaragansky cemetery (publication of the results of archaeological excavations in 1988)]. In Zdanovich G. B. (Ed.), Materialy po arheologii i etnografii YUzhnogo Urala. Trudy muzeya-zapovednika Arkaim [Materials on archeology and ethnography of the Southern Urals. Proceedings of the Arkaim Museum]. [in Russian]

Carpelan, Ch., \& Parpola, A. (2017). On the emergence, contacts and dispersal of Proto-Indo-European, Proto-Uralic and Proto-Aryan in an archaeological perspective. In A. Hyllested, B. N. Whitehead, Th. Olander, B. A. Olsen (Eds.), Language and Prehistory of the IndoEuropean Peoples: A Cross-Disciplinary Perspective (pp. 77-88). Copenhagen: Museum Tusculanum Press.

Chernikov, S. S. (1960). Vostochnyj Kazahstan v epohu bronzy [Eastern Kazakhstan in the Bronze Age]. Moscow, Leningrad: Nauka. [in Russian]

Chernykh, E. N. (1983). Problema obshhnosti kul'tur valikovoj keramiki v stepjah Evrazii [The problem of cultures of the Cordoned Ware Commonality in the steppes of Eurasia]. In G. B. Zdanovich (Ed.), Bronzovyj vek stepnoj polosy Uralo-Irtyshskogo mezhdurech'ja [Bronze Age of the steppe belt of the Ural-Irtysh interfluve] (pp. 81-99). Chelyabinsk: Bashkir State University. [in Russian]

Chernykh, E. N. (2007). Kargaly: fenomen i paradoksy razvitija; Kargaly v sisteme metallurgicheskih provincij [Kargaly: a phenomenon and paradoxes of development; Kargaly in the system of metallurgical provinces]. Moscow: Jazyki slavjanskoj kul'tury. [in Russian]

Epimakhov, A. V. (2016). K voprosu o radiouglerodnoj argumentacii rannej datirovki alakul'skih drevnostej [On the problem of radiocarbon argumentation of the early dating of Alakul antiquities]. Vestnik Arheologii, Antropologi i Etnografii [Journal of Archeology, Anthropology and Ethnography], 3 (34), 60-67. [in Russian]

Evdokimov, V. V. (1983). Hronologija i periodizacija pamjatnikov jepohi bronzy Kustanajskogo Pritobol'ja [Chronology and periodization of the Bronze Age sites in the Kustanai Tobol area]. In G. B. Zdanovich (Ed.), Bronzovyj vek stepnoj polosy Uralo-Irtyshskogo mezhdurech'ja [Bronze Age of the steppe belt of the Ural-Irtysh interfluve] (pp. 35-47). Chelyabinsk: Bashkir State University. [in Russian]

Evdokimov, V. V., \& Varfolomeev, V. V. (2002). Epoha bronzy Central'nogo i Severnogo Kazahstana [Bronze Age of Central and Northern Kazakhstan]. Karaganda: Karaganda University. [in Russian]

Fedorova-Davydova, E. A. (1973). K probleme andronovskoj kul'tury [On the problem of Andronovo culture]. In A. P. Smirnov (Ed.), Problemy arheologii Urala i Sibiri [Problems of archeology of the Urals and Siberia] (pp. 133-152). Moscow: Nauka. [in Russian]

Formozov A. A. (1951). K voprosu o proishozhdenii andronovskoj kul'tury [On the origin of the Andronovo culture]. Kratkie soobshhenija instituta material'noj kul'tury [Brief Communications of the Institute of Material Culture], 39, 3-18. [in Russian]

Garner, J. (2013). Das Zinn der Bronzezeit in Mittelasien II. Berlin: Archäologisches Institut, Bochum: Deutsches Bergbau-Museum.

Gening, V. F. (1975). Hronologicheskie kompleksy XVI v. do n. je. (po materialam Sintashtinskogo mogil'nika) [Chronological complexes of the XVI century BC (based on the materials of the Sintashta cemetery)]. In Novejshie otkrytija sovetskih arheologov (tezisy) [The latest discoveries of Soviet archaeologists] (pp. 94-95). Part 1. Kiev. [in Russian]

Gening, V. F., (1977). Mogil'nik Sintashta i problemy rannih indoiranskih plemen [Sintashta cemetery and problems of the early Indo-Iranian tribes]. Sovetskaja Arheologija [Soviet Archeology], 4, 53-73. [in Russian]

Gening, V. F., Zdanovich, G. B., \& Gening, V. V. (1992). Sintashta. Chelyabinsk: South Ural Publishing House. [in Russian]

Görsdorf, J. (2003). Datierungsergebnisse des Berliner 14C Labors 2002. Eurasia Antiqua, 9, 359-366.

Grigoriev, S. A. (1996). Sintashta i arijskie migracii vo II tys. do n.e. [Sintashta and Aryan migrations in the II millennium BC]. In S. A. Grigoriev (Ed.), Novoe v arheologii Juzhnogo Urala [New in archeology of the Southern Urals] (pp. 78-96). Chelyabinsk: Rifej. [in Russian]

Grigoriev, S. A. (1999). Drevnie indoevropejcy. Opyt istoricheskoj rekonstrukcii [Ancient Indo-Europeans. Historical reconstruction]. Chelyabinsk: Rifej. [in Russian]

Grigoriev, S. A. (2000). Bronzovyj vek [Bronze Age]. In N. O. Ivanova (Ed.), Drevnjaja istorija Juzhnogo Zaural'ja. T. I: Kamennyj vek. Epoha bronzy [Ancient History of the Southern Transurals. Vol. I: Stone Age. Bronze Age] (pp. 241-409). Chelyabinsk: South Ural State University. [in Russian]

Grigoriev, S. A. (2002). Ancient Indo-Europeans. Chelyabinsk: Rifei.

Grigoriev, S. A. (2003). Istorija izuchenija epohi bronzy Juzhnogo Zaural'ja [The history of the study of the Bronze Age in the Southern Transurals]. In N. O. Ivanova (Ed.), Istorija arheologii Juzhnogo Zaural'ja [History of Archeology of the Southern Transurals] (pp. 40-112). Chelyabinsk: Chelyabinsk State University. [in Russian]

Grigoriev, S. A. (2006). Epoha bronzy. Osnovnye etapy i problemy kul'turogeneza v Zaural'e v jepohu pozdnej bronzy [The Bronze Age. The main stages and problems of cultural genesis in the Transurals in the Late Bronze Age]. In S. G. Botalov, S. A. Grigoriev, S. Yu. Gutsalov, V. S. Mosin \& S. A. Tairov (Eds.), Arheologija Juzhnogo Urala. Step' [Archeology of the Southern Urals. Steppe] (pp. 188-222). Chelyabinsk: Rifej. [in Russian]

Grigoriev, S. A. (2008). Prostranstvennyj analiz pamjatnikov jepohi bronzy Juzhnogo Zaural'ja [Spatial analysis of the Bronze Age sites of the Southern Transurals]. Voprosy arheologii Urala [Archeology of the Urals], 25, 175-193. [in Russian]

Grigoriev, S. A. (2016). Problema hronologii i proishozhdenija alakul'skoj kul'tury v svete novyh raskopok v Juzhnom Zaural'e [The problem of the chronology and origin of Alakul culture in the light of new excavations in the Southern Transurals], Vestnik Arheologii, Antropologi i Etnografii [Journal of Archeology, Anthropology and Ethnography], 3 (34), 44-53. [in Russian] 
Grigoriev, S. A. (2017). Social processes in Ancient Eurasia and development of types of alloys in metallurgical production. Archaeoastronomy and Ancient Technologies, 5 (2), 17-44.

Grigoriev, S. A., Petrova, L. Ju., Pleshanov, M. L., Gushchina, E. V., \& Vasina, Ju. V. (2018). Poselenie Mochishhe i andronovskaja problema [The settlement of Mochishche and the Andronovo problem]. Chelyabinsk: Cicero. [in Russian]

Gryaznov, M. P. (1927). Pogrebenija bronzovoj epohi v Zapadnom Kazahstane [Burials of the Bronze Age in Western Kazakhstan]. Kazaki, Leningrad, 2, 172-221. [in Russian]

Hanks, B. K., Epimakhov, A. V., \& Renfrew, A. C. (2007). Towards a refined chronology for the Bronze Age of the southern Urals, Russia. Antiquity, 81, 353-367.

Ilyushina, V. V. (2015). Keramika fedorovskoj kul'tury poselenija Shhetkovo 2 v Nizhnem Pritobol'e (rezul'taty tehniko-tehnologicheskogo analiza) [Ceramics of the Fyodorovka culture of the settlement of Shchetkovo 2 in the Lower Tobol area (results of technical and technological analysis)]. Vestnik Arheologii, Antropologi i Etnografii [Journal of Archeology, Anthropology and Ethnography], 4 (31), 38-47. [in Russian]

Itina, M. A. (1977). Istoriya stepnyh plemyon Yuzhnogo Priaral'ya (II - nachalo I tysyacheletiya do n.e.) [History of the steppe tribes of the Southern Aral Sea region (II - early I millennium BC)]. Moscow: Nauka.

Ivanov, S. S. (2014). Novye nahodki ornamentirovannyh visloobushnyh toporov jepohi bronzy iz Kyrgyzstana [New finds of ornamental axes from Kyrgyzstan]. Teorija i praktika arheologicheskih issledovanij [Theory and practice of archaeological research], 1(9), 91-100. [in Russian]

Khlobystin, L. P. (1976). Poselenie Lipovaja Kur'ja [Settlement of Lipovaya Kurya]. Leningrad: Nauka. [in Russian]

Kiryushin, Ju. F., Grushin, S. P., \& Leontieva, D. S. (2016). Andronovskoe poselenie Shljapovo v Verhnem Priobie [Andronovo settlement of Shlyapovo in the Upper Ob]. Vestnik Arheologii, Antropologi i Etnografii [Journal of Archeology, Anthropology and Ethnography], 1 (32), 44-54. [in Russian]

Kiyashko, A. V. (2002). Kul'turogenez na vostoke katakombnogo mira [Cultural Genesis in the East of the Catacomb World]. Volgograd: Volgograd University. [in Russian]

Korfmann, M. (1983). Demircihüyük. Die Ergebnisse der Ausgrabungen 1975 - 1978. BI. Architektur, Stratigraphie und Befunde. Meinz am Rhein: Philipp von Zabern.

Korochkova, O. N., Stefanov, V. I., \& Spiridonov, I. A. (2020). Svjatilishhe pervyh metallurgov Srednego Urala [Sanctuary of the first metallurgists of the Middle Urals]. Ekaterinburg: Ural'skij universitet. [in Russian]

Korochkova, O. N., \& Stefanov, V. I. (2001). O fedorovskih drevnostjah Zaural'ja [About Fyodorovka Antiquities of the Transurals]. In XV Ural'skoe arheologicheskoe soveshhanie: Tezisy dokladov [XV Ural Archaeological Conference: Abstracts] (pp. 83-84). Orenburg: Orenburgskaja gubernija. [in Russian]

Koryakova, L. N., \& Epimakhov, A. V. (2007). The Urals and Western Siberia in the Bronze and Iron Age. Cambridge: Cambridge University Press.

Koryakova, L. N., Krause, R., Epimakhov, A. V., Sharapova, S. V., Panteleyeva, S. E., Berseneva, N. A., Fornasier, J., Kaiser, E., Molchanov, I. V., \& Chechushkov, I. V. (2011). Archaeological Studies of the Kamenny Ambar (Olgino) Fortified Settlement. Archaeology, ethnology \& anthropology of Eurasia, 39 (4), 61-74.

Kosarev, M. F. (1981). Bronzovyj vek Zapadnoj Sibiri [Bronze Age of Western Siberia]. Moskva: Nauka. [in Russian]

Krause, R., Epimakhov, A. V., Kupriyanova, E. V., Novikov, I. K., \& Stolyarchik, Je. (2019). Petrovskie pamjatniki bronzovogo veka: problemy taksonomii i hronologii [Petrovka monuments of the Bronze Age: problems of taxonomy and chronology]. Archaeology, Ethnology and Anthropology of Eurasia, 47 (1), 54-63. [in Russian]

Krivtsova-Grakova, O. A. (1948). Alekseevskoe poselenie i mogil'nik [Alexeevskoe settlement and burial ground]. Moscow: GIM. [in Russian]

Kupriyanova, E. V. (2015). Stilevye variacii keramicheskogo kompleksa mogil'nika Stepnoe VII v socio-kul'turnom aspekte funkcionirovanija nekropolej jepohi bronzy Juzhnogo Zaural'ja [Style variations of the ceramic complex of the Stepnoe VII cemetery in the socio-cultural aspect of the functioning of the necropolises of the Bronze Age of the Southern Transurals]. In E. V. Kupriyanova \& D. G. Zdanovich. Drevnosti lesostepnogo Zaural'ja: mogil'nik Stepnoe VII [Antiquities of the forest-steppe Transurals: burial ground of Stepnoe VII] (pp. 144-178). Chelyabinsk: Enciklopediya. [in Russian]

Kuz'mina, E. E. (1961). Rezul'taty rabot na Embe v 1958 g. [Results of work on Emba in 1958]. Kratkie soobshcheniya Instituta Arheologii [Brief reports of the Institute of Archeology], 85, 85-94. [in Russian]

Kuz'mina, E. E. (1964). Periodizacija mogil'nikov Elenovskogo mikrorajona andronovskoj kul'tury [Periodization of burial grounds of the Elenovka area of Andronovo culture]. In O. N. Bader (Ed.), Pamjatniki kamennogo i bronzovogo vekov Evrazii [Sites of the Stone and Bronze Ages of Eurasia] (pp. 121-140). Moscow: Nauka. [in Russian]

Kuz'mina, E. E. (1986). O nekotoryh arheologicheskih aspektah problemy proishozhdenija indo-irancev [About some archaeological aspects of the problem of origins of the Indo-Iranians]. In I. M. Diakonov (Ed.), Peredneaziatskij sbornik: Drevnjaja i srednevekovaja istorija i filologija stran Perednego i Srednego Vostoka [The Near Eastern miscellanea: Ancient and Medieval History and Philology of the Countries of the Near and Middle East] (pp. 169-228). Moscow: Nauka. [in Russian]

Kuz'mina, E. E. (1994). Otkuda prishli indoarii? [Where did the Indo-Aryans come from?]. Moscow: Nauka. [in Russian]

Kuz'mina, E. E. (2001). Mesto andronovskoj kul'turnoj obshchnosti v Evrazii [The place of the Andronovo cultural commonality in Eurasia]. In XV Ural'skoe arheologicheskoe soveshchanie. Tezisy dokladov [XV Ural archaeological meeting. Abstracts] (p. 87-90). Orenburg: Orenburgskaja guberhiya. [in Russian]

Kuz'mina, E. E. (2007). The origin of the Indo-Iranians. Leiden, Boston: Brill. 
Logvin, A. V., \& Shevnina, I. V. (2013). Poselenie Konezavod I [The settlement of Konezavod I]. In V. G. Loman (Ed.), Arheologicheskie issledovanija stepnoj Evrazii [Archaeological studies of steppe Eurasia] (pp. 103-113). Karaganda: TENGRI Ltd. [in Russian]

Loman, V. G. (2013). 0 kul'turnyh tipah pamjatnikov finala epohi bronzy Kazahstana [On the cultural types of monuments of the final of the Bronze Age of Kazakhstan]. In A. Z. Beisenov (Ed.). Begazy-dandybaevskaja kul'tura stepnoj Evrazii [Begazi-Dandybay culture of steppe Eurasia] (pp. 247-259). Almaty: Begazi-Tasmola. [in Russian]

Mallory, J. P., \& Adams, D. Q. (1997). Enciclopedia of Indo-European studies, London: Fitzroy Dearborn Publishers.

Malyutina, T. S., Zdanovich, G. B., \& Petrova L. Ju. (2006). Poselenie Bersuat XVIII [Settlement of Bersuat XVIII]. In S. G. Botalov, S. A. Grigoriev, S. Yu. Gutsalov, V. S. Mosin \& S. A. Tairov (Eds.), Arheologija Juzhnogo Urala. Step' [Archeology of the Southern Urals. Steppe] (pp. 153-172). Chelyabinsk: Rifej. [in Russian]

Margulan, A. H., Akishev, K. A., Kadyrbaev, M. K., \& Orazbaev, A. M. (1966). Drevnjaja kul'tura Central'nogo Kazahstana [Ancient culture of Central Kazakhstan]. Alma-Ata: Nauka. [in Russian]

Mathieson, I., Lazaridis, I., Rohland, N., Mallick, S., Patterson, N., Roodenberg, S. A., Harney, E., Stewardson, K., Fernandes, D., Novak, M., Sirak, K., Gamba, C., Jones, E. R., Llamas, B., Dryomov, S., Pickrell, J., Arsuaga, J. L., de Castro, J. M., Carbonell, E., Gerritsen, F., .. . Reich, D. (2015). Genome-wide patterns of selection in 230 ancient Eurasians. Nature, 528 (7583), 499-503. https://doi.org/10.1038/ nature16152

Matveev, A. V. (1998). Pervye andronovcy v lesah Zaural'ja [The first Andronovo people in the forests of the Transurals]. Novosibirsk: Nauka. [in Russian]

Matveev, A. V. (2007). Cherkaskul'skaja kul'tura Zaural'ja [Cherkaskul culture of the Transurals]. Ab Origine, 1, 4-41. [in Russian]

Matveev, A. V. Volkov, E. N., Kostomarova, Ju. V. (2007). Materialy novyh raskopok Hripunovskogo mogil'nika [Materials of new excavations of the Khripunovsky cemetery]. In M. P. Vohmentsev (Ed.), Problemy arheologii: Ural i Zapadnaja Sibir' [Problems of Archeology: Urals and Western Siberia] (pp. 108-113). Kurgan: Kurgan University. [in Russian]

Mei, J. (2000). Copper and Bronze Metallurgy in Late Prehistoric Xinjiang. Its cultural context and relationship with neighbouring regions. Oxford: Archaeopress.

Mei, J., \& Shell, C. (1999). The existence of Andronovo cultural influence in Xinjiang during the 2nd millennium BC. Antiquity. 73, 570-578.

Mochalov, O. D. (2008). Keramika pogrebal'nyh pamjatnikov jepohi bronzy lesostepi Volgo-Ural'skogo mezhdurech'ja [Ceramics of funeral monuments of the Bronze Age of the forest-steppe in the Volga-Ural interfluve]. Samara: Samara State Pedagogical University. [in Russian]

Molodin, V. I., Epimakhov, A. V., \& Marchenko, Zh. V. (2014). Radiouglerodnaja hronologija kul'tur jepohi bronzy Urala i juga Zapadnoj Sibiri: principy i podhody, dostizhenija i problemy [Radiocarbon chronology of cultures of the Bronze Age of the Urals and the south of Western Siberia: principles and approaches, achievements and problems]. Novosibirsk State University Bulletin. Series: History and Philology, 13 (3), 136-167. [in Russian]

Murzin, V. Ju. (1990). Proishozhdenie skifov: osnovnye etapy formirovanija skifskogo etnosa [The origin of the Scythians: the main stages in the formation of the Scythian ethnos]. Kiev: Naukova dumka. [in Russian]

Obydennov, M. F., \& Shorin, A. F. (1995). Arheologicheskie kul'tury pozdnego bronzovogo veka drevnih ural'cev (cherkaskul'skaja i mezhovskaja kul'tury) [Archaeological cultures of the late Bronze Age of the ancient Urals (Cherkaskul and Mezhovka cultures)]. Ekaterinburg: Ural University. [in Russian]

Panyushkina, I. P., Mills, B. J., Usmanova, E. R., \& Cheng, L. (2008). Calendar age of Lisakovsky timbers attributed to Andonovo community of Bronze Age in Eurasia. Radiocarbon, 50, 459-469.

Parpola, A. (2012). Formation of the Indo-European and Uralic (Finno-Ugric) language families in the light of archaeology: Revised and integrated 'total' correlations. In R. Grünthal \& P. Kallio (Eds.), A Linguistic Map of Prehistoric Northern Europe (pp. 119-184). Helsinki: Suomalais-Ugrilaisen Seuran Toimituksia.

Potemkina, T. M. (1975). Keramicheskie kompleksy Alekseevskogo poselenija na r. Tobol [Ceramic complexes of Alekseevskoye settlement on the river Tobol]. Sovetskaja Arheologija [Soviet Archaeology], 1, 35-50. [in Russian]

Potemkina, T. M. (1983). O proishozhdenii alakul'skoj kul'tury [On the origin of Alakul culture]. In G. B. Zdanovich (Ed.), Bronzovyj vek stepnoj polosy Uralo-Irtyshskogo mezhdurech'ja [Bronze Age of the steppe belt of the Ural-Irtysh interfluve] (pp. 8-21). Chelyabinsk: Bashkir State University. [in Russian]

Potemkina, T. M. (1985). Bronzovyj vek lesostepnogo Pritobol'ja [Bronze Age of the forest-steppe Tobol area]. Moscow: Nauka. [in Russian]

Potemkina, T. M. (1994). Rol' abashevcev v processe razvitija alakul'skoj kul'tury [The role of the Abashevo people in the development of Alakul culture]. In Pryakhin (Ed.), Epoha bronzy vostochno-evropejskoj lesostepi [Bronze Age of the East European Forest-Steppe] (pp. 77-108). Voronezh. [in Russian]

Pyatykh, G. G. (2003). K probleme prinadlezhnosti Potapovskogo mogil'nika k "Sintashtinskoj kul'ture” [On the problem of belonging of the Potapovka cemetery to the "Sintashta culture"]. In Abashevskaya kul'turno-istoricheskaya obshchnost': istoki, razvitie, nasledie. Materialy mezhdunarodnoj nauchnoj konferencii [Abashevo cultural and historical commonality: origins, development, heritage. Materials of international scientific conference] (pp. 138-142). Cheboksary: ChGIGN.

Ryabogina, N. E., Matveeva, N. P., \& Orlova, L. A. (2001). Novye dannye o prirodnoj srede Zaural'ja v drevnosti (palinologicheskoe issledovanie otlozhenij Nizhne-Ingal'skogo-3 poselenija) [New data on the natural environment of the Transurals in antiquity (palynological study of sediments of the Nizhneingalskoe-3 settlement)]. Vestnik Arheologii, Antropologi i Etnografii [Journal of Archeology, Anthropology and Ethnography], 3, 205-212. [in Russian] 
Salnikov, K. V. (1948). K voprosu o stadijah v pamjatnikah andronovskoj kul'tury Zaural'ja [To the question of the stages in the monuments of Andronovo culture of the Transurals]. In Pervoe Ural'skoe arheologicheskoe soveshhanie [The first Ural archaeological meeting] (pp. 21-26). Molotov. [in Russian]

Salnikov, K. V. (1951). Bronzovyj vek Juzhnogo Zaural'ja [Bronze Age of the Southern Transurals]. In A. Ja. Bryusov (Ed.), Materialy i issledovanija po arheologii SSSR [Materials and research on archeology of the USSR], 21, Vol. II (pp. 94-151). Moscow: Nauka. [in Russian]

Salnikov, K. V. (1964). Nekotorye voprosy istorii lesnogo Zaural'ja v epohu bronzy [Some questions of the history of the forest Transurals in the Bronze Age]. Voprosy Arheologii Urala [Archeology of the Urals], 6, 24-37. [in Russian]

Salnikov, K. V. (1967). Ocherki drevnej istorii Juzhnogo Urala [Essays on the ancient history of the Southern Urals]. Moscow: Nauka. [in Russian]

Smirnov, K. F., \& Kuz'mina, E. E. (1976). Rannie pogrebal'nye kompleksy pod Orskom i problema hronologicheskogo sootnoshenija kul'tur jepohi bronzy Priural'ja [Early burial complexes near Orsk and the problem of the chronological correlation of cultures of the Bronze Age in the Urals]. In I. B. Vasiliev (Ed.), Problemy arheologii Povolzh'ja i Priural'ja [Problems of archeology of the Volga and Ural regions] (pp. 45-47). Kuybyshev: Pedagogical Institute. [in Russian]

Smirnov, K. F., \& Kuz'mina, E. E. (1977). Proishozhdenie indoirancev v svete novejshih arheologicheskih otkrytij [The origin of the IndoIranians in the light of the latest archaeological discoveries]. Moscow: Nauka. [in Russian]

Stefanov, V. I. (1996). Poselenija alakul'skoj kul'tury Juzhnogo Urala. In N. O. Ivanova (Ed.), Materialy po arheologii i jetnografii Juzhnogo Urala [Materials on archeology and ethnography of the Southern Urals] (pp. 43-63). Chelyabinsk: Kamennyj pojas. [in Russian]

Stefanov, V. I., \& Korochkova, O. N. (2000). Andronovskie drevnosti Tjumenskogo Pritobol'ja [Andronovo antiquities of the Tyumen Tobol area]. Ekaterinburg: Poligrafist. [in Russian]

Stefanov, V. I., \& Korochkova, O. N. (2004). Alakul'skaja i fedorovskaja kul'tury v lesostepnom Zaural'e: problemy vzaimodejstvija [Alakul and Fyodorovka cultures in the forest-steppe Transurals: problems of interaction]. Rossijskaja Arheologija [Russian Archeology], 4, 52-66. [in Russian]

Stefanov, V. I., \& Korochkova, O. N. (2006). Urefty I: zaural'skij pamjatnik vandronovskom kontekste [Urefty I: Transural monument in the Andronovo context]. Ekaterinburg: Ural University. [in Russian]

Stokolos, V. S. (1972). Kul'tura naselenija bronzovogo veka Juzhnogo Zaural'ja [The culture of the Bronze Age population of the Southern Transurals]. Moscow: Nauka. [in Russian]

Teploukhov, S. A. (1927). Drevnie pogrebenija v Minusinskom krae [Ancient burials in the Minusinsk Territory]. In Materialy po jetnografii [Ethnographic materials]. Vol. III, 2, (pp. 57-112). Leningrad: Russian Museum. [in Russian]

Tkachev, V. V. (2007). Stepi Juzhnogo Priural'ja i Zapadnogo Kazahstana na rubezhe jepoh srednej i pozdnej bronzy [Steppes of the Southern Urals and Western Kazakhstan at the transition from the Middle to the Late Bronze Age]. Aktobe: Aktjubinskij centr istorii, jetnografii $\mathrm{i}$ arheologii. [in Russian]

Tkacheva, N. A., \& Tkachev, A. A. (2008). Epoha bronzy Verhnego Priirtysh'ja [The Bronze Age of the Upper Irtysh Region]. Novosibirsk: Nauka. [in Russian]

Usmanova, E. R., \& Panyushkina I. P. (2011). Andronovskie pamjatniki Lisakovskoj okrugi [Andronovo Monuments of Lisakovsk District]. In Arheologija Kazahstana v jepohu nezavisimosti: itogi, perspektivy: Materialy mezhdunarodnoj nauchnoj konferencii, posvjashhennoj 20-letiju Nezavisimosti Respubliki Kazahstan i 20-letiju Instituta arheologii im. A.H. Margulana KN MON RK [Archeology of Kazakhstan in the era of independence: results, prospects: Materials of the international scientific conference dedicated to the 20th anniversary of Independence of the Republic of Kazakhstan and the 20th anniversary of the Institute of Archeology named after A.Kh. Margulan KN MON RK] (pp. 375-380). Almaty. [in Russian]

Vasiliev, I. B., Kuznetsov, P. F., \& Semenova, A. P. (1995). Pamjatniki potapovskogo tipa v lesostepnom Povolzh'e (kratkoe izlozhenie koncepcii). [Monuments of the Potapovka type in the forest-steppe Volga region (a brief summary of the concept)] In I. B. Vasiliev (Ed.), Drevnie indoiranskie kul'tury Volgo-Ural'ja (II tys. do n.je.) [Ancient Indo-Iranian cultures of the Volga-Ural region (II millennium BC)] (pp. 5-37). Samara: State pedagogical university. [in Russian]

Vinogradov, N. B. (1982). Kulevchi III - pamjatnik petrovskogo tipa v Juzhnom Zaural'e [Kulevchi III - a monument of Petrovka type in the Southern Transurals]. Kratkie soobshhenija Instituta Arheologii [Brief Communications of the Institute of Archaeology], 169, 94-99. [in Russian]

Vinogradov, N. B. (1995). Hronologija, soderzhanie i kul'turnaja prinadlezhnost' pamjatnikov sintashtinskogo tipa bronzovogo veka v Juzhnom Zaural'e [Chronology, content and cultural affiliation of Sintashta-type monuments of the Bronze Age in the Southern Transurals]. Vestnik Cheljabinskogo gosudarstvennogo pedagogicheskogo universiteta. Istoricheskie nauki [Bulletin of the Chelyabinsk State Pedagogical University. Historical sciences], 1, 16-26. [in Russian]

Vinogradov, N. B. (2011). Stepi Juzhnogo Urala i Kazahstana v pervye veka Il tys. do n.e. (pamjatniki sintashtinskogo i petrovskogo tipa) [Steppes of the Southern Urals and Kazakhstan in the first centuries of the 2nd millennium BC (monuments of the Sintashta and Petrovka type)]. Chelyabinsk: Abris. [in Russian]

Vinogradov, N. B. (2013). Drevnee Ust'e: ukreplennoe poselenie bronzovogo veka v Juzhnom Zaural'e [Ancient Ustye: a fortified Bronze Age settlement in the Southern Transurals]. Chelyabinsk: Abris. [in Russian]

Zakh, V. A. (2014). Formirovanie fedorovskoj kul'tury v Pritobol'e i puti migracii ee nositelej na vostok [Formation of Fyodorovka culture in the Tobol area and ways of migration of its bearers to the east]. Vestnik Arheologii, Antropologi i Etnografii [Journal of Archeology, Anthropology and Ethnography], 1 (24), 50-60. [in Russian] 
Zakh, V. A., Ryabogina, N. E., Ilyushina, V. V., Ivanov, S. N., \& Murzina E. I. (2013). Fedorovskij poselok Kur'ja 1 v sisteme Andreevskih ozer [Fyodorovka settlement of Kurya 1 in the system of Andreeevskiye Lakes]. Vestnik Arheologii, Antropologi i Etnografii [Journal of Archeology, Anthropology and Ethnography], 1 (20), 10-23. [in Russian]

Zdanovich, G. B. (1973). Keramika epohi bronzy Severo-Kazahstanskoj oblasti [Ceramics of the Bronze Age of the North Kazakhstan Region]. Archaeology of the Urals, 12, 21-43. [in Russian]

Zdanovich, G. B. (1983). Osnovnye harakteristiki petrovskih pamjatnikov Uralo-Kazahstanskih stepej (k voprosu o vydelenii petrovskoj kul'tury) [The main characteristics of Petrovka sites of the Ural-Kazakhstan steppes (on the problem of identification of Petrovka culture)]. In G. B. Zdanovich (Ed.), Bronzovyj vek stepnoj polosy Uralo-Irtyshskogo mezhdurech'ja [Bronze Age of the steppe belt of the Ural-Irtysh interfluve] (pp. 48-68). Chelyabinsk: Bashkir State University. [in Russian]

Zdanovich, G. B. (1984). Otnositel'naja hronologija pamjatnikov bronzovogo veka uralo-kazahstanskih stepej [Relative chronology of the Bronze Age sites of the Ural-Kazakhstan steppes]. In V. F. Zaibert, S. Ya. Zdanovich (Eds.). Bronzovyj vek Uralo-Irtyshskogo mezhdurech'ja [Bronze Age of the Ural-Irtysh interfluve] (pp. 3-22). Chelyabinsk: Bashkir State University. [in Russian]

Zdanovich, G. B. (1988). Bronzovyj vek Uralo-Kazahstanskih stepej (osnovy periodizacii) [Bronze Age of the Ural-Kazakhstan steppes (the basis of periodization)]. Sverdlovsk: Ural University. [in Russian]

Zdanovich, G. B. (1997). Arkaim - kul'turnyj kompleks epohi srednej bronzy Juzhnogo Zaural'ja [Arkaim - a cultural complex of the Middle Bronze Age of the Southern Transurals]. Rossijskaja Arheologija [Russian Archaeology], 2, 47-62. [in Russian]

Zdanovich, G. B., \& Batanina, I. M. (2007). Arkaim - strana gorodov: Prostranstvo i obrazy (Arkaim: gorizonty issledovanij). [Arkaim Country of Towns: Space and Images (Arkaim: Horizons of Research)]. Chelyabinsk: Crocus. [in Russian]

Zdanovich, S. Ya. (1984). Keramika sargarinskoj kul'tury [Ceramics of the Sargari culture]. In V. F. Zaibert, S. Ya. Zdanovich (Eds.). Bronzovyj vek Uralo-Irtyshskogo mezhdurech'ja [Bronze Age of the Ural-Irtysh interfluve] (pp. 79-96). Chelyabinsk: Bashkir State University. [in Russian]

Zyryanov, A. N. (1863). Kurgany u s. Zamaraevskogo, Shadrinskogo uezda, Permskoj gub. Izvestija imperatorskogo arheologicheskogo obshhestva [Mounds near the village Zamaraevo, Shadrinsk district, Perm' region. News of the imperial archaeological society]. T. IV. Sankt-Petersburg. [in Russian] 